\title{
An Interdisciplinary Erosion Mitigation Approach for Coral Reef Protection - A Case Study from the Eastern Caribbean
}

\author{
Carlos E. Ramos-Scharrón ${ }^{1,2}$, \\ Juan M. Amador ${ }^{3}$ and Edwin A. Hernández-Delgado 4,5 \\ ${ }^{1}$ Island Resources Foundation, \\ ${ }^{2}$ Department of Geography \& the Environment, the University of Texas-Austin, \\ ${ }^{3}$ Greg L. Morris Engineering COOP, \\ ${ }^{4}$ Center for Applied Tropical Ecology and Conservation, \\ University of Puerto Rico-Río Piedras, \\ ${ }^{5}$ Caribbean Coral Reefs Institute, \\ University of Puerto Rico-Mayagüez, \\ ${ }^{1}$ US Virgin Islands \\ 2USA \\ 3,4,5 Puerto Rico
}

\section{Introduction}

\subsection{Project background}

Although evidence suggests that the onset of worldwide coral reef degradation dates back to centuries ago, it is unequivocal that human impacts are to some degree responsible for their current frail condition (Jackson, 1997, 2001; Pandolfi et al., 2003). Reefs of the Caribbean have not escaped this global trend as studies have noted an unprecedented increase in the spatial and temporal scale of coral reef turnover events, apparently rooted in the accelerating pace of regional-level ecological change (Aronson et al., 2002). Recent impacts appear to have changed coral community structure in ways not observed in the region over the last 220,000 years (Pandolfi and Jackson, 2006). The generalized decline in coral cover observed throughout the Caribbean has been associated with the heightened prevalence of both regional pressures (e.g., warmer sea surface temperatures, bleaching, and higher incidence of disease) and local stressors (e.g., non-point sources of pollution, fishing, etc.) (Rodríguez, 1981; Gardner et al., 2003, Hawkins and Roberts, 2004; Pandolfi et al., 2005; Miller et al., 2006, 2009). In addition, climate change projections suggest a more challenging future for Caribbean coral reef ecosystems (Hoegh-Guldberg, 1999; Hoegh-Guldberg et al., 2007; Buddemeier et al., 2008, 2010; Hernández-Pacheco et al., 2011).

Coral reefs in the Commonwealth of Puerto Rico (PR) are among the most highly threatened reefs of the entire Caribbean as a consequence of the combined effects of climate change, coral bleaching, increased incidence of disease, overfishing, and the delivery of inland 
pollutants (Burke and Maidens, 2004; Hernández-Delgado, 2005; Ballantine et al., 2008; García-Sais et al., 2008; Larsen and Webb, 2009; Hernández-Delgado and Sandoz-Vera, 2011). Excess delivery of land-based contaminants into the marine environment of PR cannot be considered an exclusive present-day phenomenon (Goenaga and Cintrón, 1979; Goenaga, 1991; Hernández-Delgado, 2000, 2005). Water quality is inevitably related to land use, and generally it is inversely correlated with economic development, population density, land use patterns, and other socioeconomic indicators (Biagi, 1965; Restrepo and Syvistski, 2006; Oliver et al., 2011). Therefore, the deterioration of coastal water quality in PR likely began in the mid-1800's when an island-wide wave of deforestation cleared the way for timber extraction, cattle grazing, and mass production of agricultural goods (Birdsey and Weaver, 1987). Change of sovereignty at the turn of the $20^{\text {th }}$ century from Spanish colonial rule to U.S. control favored the extensive use of coastal lowlands for sugar cane production under a progressively mechanized and more centralized system (Labadie-Eurite, 1949; Dietz, 1986) and this resulted in its own new suite of water pollutants (Biagi, 1968). Assisted by lax enforcement of environmental safeguards (Concepción, 1988; Berman-Santana, 1996) socioeconomic and political development in PR following Second World War (WWII) explicitly encouraged a move towards industrialization at the expense of agricultural production (Dietz, 1986). Even though implementation of this new economic model allowed

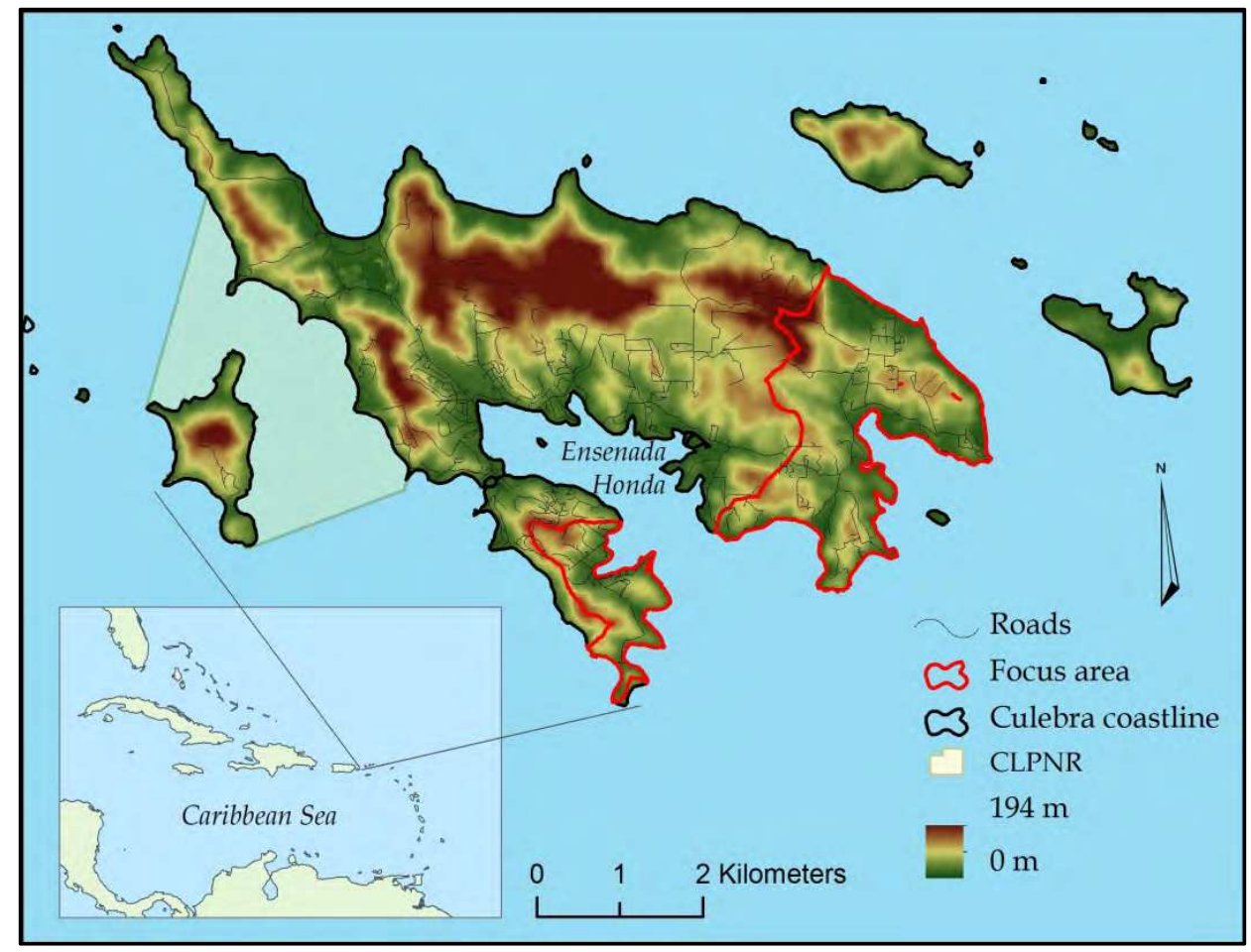

Fig. 1. Map of Isla de Culebra displaying its general location with respect to the Caribbean Region, its road network, the focus watersheds for this article, the Canal Luis Peña Marine Reserve (CLPNR), and the island's topography. 
for the recuperation of an island-wide forest cover (Rudel et al., 2000; Grau et al., 2003; Valdés-Pizzini et al., 2011), it also introduced its own new set of water quality issues (Hunter and Arbona, 1995) that have established a legacy of documented stress and detrimental effects on coral reef communities in various parts of the Puerto Rican archipelago (e.g., Loya, 1976; Goenaga and Cintrón, 1979; Goenaga, 1991; HernándezDelgado, 2000, 2005; Morelock et al., 2001; Larsen and Webb, 2009; Hernández-Delgado et al., 2010, Hernández-Delgado and Sandoz-Vera, 2011).

The island of Culebra (Figure 1) supports coral reef ecosystems characteristic of northeastern Caribbean marine biodiversity (Hernández-Delgado, 2000, 2005; Hernández-Delgado et al., 2000; García et al., 2003; Hernández-Delgado and Rosado-Matías, 2003), and they represent highly valuable sources of fishing, tourism and recreational activities (Estudios Técnicos, 2007; Webler and Jakubowski, 2011). Culebra also supports the first no-take natural reserve established in PR, the Canal Luis Peña Natural Reserve (CLPNR) (Pagán-Villegas et al., 1999), and houses various academic and community-based coral reef and reef fisheries management conservation efforts (Hernández-Delgado et al., 2011). Culebra's nearshore coral reefs have also been described as some of the most exceptional in PR (Hernández Delgado, 2000; Simonsen, 2000), and this is presumably due in part to historic low doses of terrestrial sediment inputs originating from the relatively small watersheds combined with a sub-tropical dry climatic setting. Long-term monitoring within CLPNR has shown an alarming 50-80\% decline in percent live coral cover since 1997 (Hernández-Delgado, 2010). Indirect evidence suggests that the decline in percent living coral cover may be associated with increased sedimentation resulting from recent land development, deforestation, and lack of mandatory erosion controls (Hernández-Delgado, 2004; Hernández-Delgado et al., 2006) (Figure 2), in combination with fishing pressure, climate change-related sea surface warming, massive coral bleaching, and post-bleaching mortality events (HernándezPacheco et al., 2011), as it has been documented elsewhere (Miller et al., 2006, 2009).

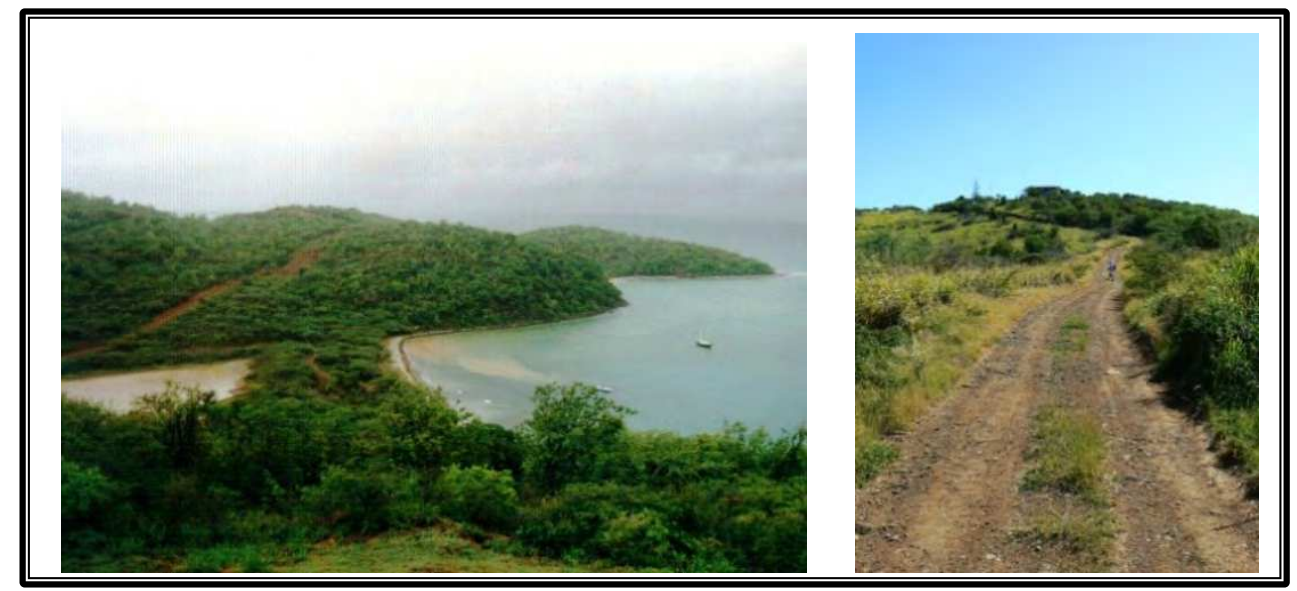

Fig. 2. (Left) Picture of a plume entering Bahía Mosquito by sediment produced from a single, unpaved road segment (photo courtesy of M.A. Lucking-CORALations). (Right) Picture of an unpaved road segment that typifies the road network in Culebra. 
Focus groups executing U.S. Coral Reef Task Force mandates have identified Culebra as a top priority site in PR needing a Local Action Strategy (LAS) plan. Two of the most important goals of the LAS efforts are to implement land-use planning at the watershed scale to minimize water quality impacts to the coral reef ecosystem, and to control and reduce pollutant transport to the marine environment. The LAS plan in Culebra is in part required to address the continuous decline in coral reef conditions by reducing the risks posed by the recent acceleration in land development rates (Commonwealth of PR and NOAA, 2010).

\subsection{Objectives}

The lack of a scientifically-based methodology to guide watershed management strategies is partly to blame for deficient to non-existent erosion control activities on Culebra and on most islands of the Caribbean. The main objective of this article is to describe an innovative framework by which technical knowledge gathered by marine ecologists, watershed scientists, and civil engineers can be best employed in the development of an erosion mitigation strategy. The approach proposed here is intended to explicitly define the principles behind the development of such interdisciplinary strategies and to maximize their benefits. Although the goal of erosion control is simply to alleviate the pressures associated with just one of the many sources of stress affecting coral reefs, the general framework described here could be emulated to address other land-based, non-point pollution sources affecting coral reef systems in Culebra and elsewhere. Isla de Culebra serves as the focus of our efforts because of its imminent need for the implementation of such types of mitigation efforts and to take advantage of previously-existing coral reef databases and watershed assessments (Hernández-Delgado 2000; Hernández-Delgado et al., 2000, 2006; HernándezDelgado and Rosado-Matías, 2003; Ramos-Scharrón, 2009).

\section{Site description}

\subsection{Natural environment}

At $26.6 \mathrm{~km}^{2}$ and located roughly $28 \mathrm{~km}$ east of mainland PR, Isla de Culebra (Latitude: 18.2; Longitude: -65.3) is the second smallest and easternmost municipality (i.e., township) comprising the Commonwealth of PR (Figure 1). Isla de Culebra consists of an irregularly shaped and roughly $10.5 \mathrm{~km}$ by $8.5 \mathrm{~km}$ main landmass (hereafter referred to as Culebra) and 20 cays. Culebra is an emergent part of the Puerto Rico-Virgin Islands microplate, a broad and tectonically active deformation zone defining the boundary of the Caribbean and Atlantic plates (Masson and Scanlon, 1991). The dominant lithology dates to the Cretaceous Period and is composed of surface volcanics (andesites) and shallow intrusives (Meyerhoff, 1927). Although the maximum elevation in Culebra is just shy of $200 \mathrm{~m}$, Culebra's topography is hilly and characterized by abrupt slopes of up to 36 degrees near the ridge tops, interrupted by flat alluvial deposits and coastal wetlands. The dominant soil type in Culebra is the generally shallow (40-65 cm thick), well-drained, and moderately permeable Descalabrado clay-loam series also found in semi-arid areas of the US Virgin Islands (USVI) and southwestern PR (Beinroth et al., 2003). The annual rainfall rate in Culebra is close to $990 \mathrm{~mm}$ per year and the average temperature is about $26-27^{\circ} \mathrm{C}$ (PR-EQB, 1970; USACE, 1995). Hence, the island displays a sub-tropical dry type of vegetation typical of low altitude tropical forests with high evapotranspiration but low annual rainfall rates (Ewel and Whitmore, 1973). Watersheds are small with none exceeding more than $2-3 \mathrm{~km}^{2}$ and are drained by poorly defined, intermittent streams. 
Culebra is surrounded by a large system of fringing reefs, rocky bottoms, hard grounds and mid-shelf reefs which are representative of the northeastern Caribbean (HernándezDelgado, 2005). Windward side reefs generally have extensive structural development, including some spur and groove systems. However, many still display significant physical destruction associated to the impacts of Hurricanes David and Frederic in 1979, Hugo in 1989, Marilyn in 1995, and Georges in 1998 (Garrison et al., 2005). Some extensively developed linear fringing reef structures include some of our study sites (i.e., Ensenada Malena, Cayo Dákity, Ensenada Almodóvar, Puerto Del Manglar, and Playa Larga). There are also extensive systems of discontinuous fringing and patch reefs, like those in the Punta Soldado and Playa Zoní areas. There is also an extensive system of mid-shelf reefs from about 1 to 5 miles off the eastern and southeastern coasts of the island, as well as an extensive and poorly studied system of mesophotic coral reef communities extending from Culebra to the east towards St. Thomas, U.S. Virgin Islands.

\subsection{Land use history}

Although the number and significance of archaeological findings in Culebra have yet to match the magnificence or relevance of those uncovered in the nearby Isla de Vieques and mainland PR, evidence still suggests that the island was transiently inhabited by various groups of Amerindians during pre-colonial times (Hernández-Delgado et al. 2003). No evidence exists of any permanent human presence in Culebra until 1880 when a Spanish decree promoted settlement and habilitation for agricultural production and cattle grazing. In 1901, only three years following the transition of the entire Puerto Rican territory from the Spanish Crown to the United States, the US Navy began to establish a presence on the island. Paradoxically, while areas of Culebra came to house the first wildlife refuge of the entire Insular Caribbean (established in 1909), other nearby areas became live ammunition training grounds for the US Navy's Atlantic Fleet. During and following the WWII access to the island became severely restricted and this is presumed to have had long-term repercussions on the island as it severed Culebra from the new economic plan being propelled over the rest of PR (Estudios Técnicos Inc., 2004). Some sense of civilian normalcy was finally achieved in Culebra following the ouster of the US Navy in 1978.

Land development on Culebra occurred at a rather slow rate over the initial years following 1978 but it has experienced an accelerated pace since the late 1990's. Contemporary land development practices on Culebra generally consists of vegetation removal, combined with ground leveling and compaction associated to construction (e.g., individual home sites) and opening of low-standard, steep roads that tend to remain unpaved and exposed to erosion over relatively long periods (Figure 2). Land disturbance is achieved by heavy machinery and generally lacks construction-phase mandatory erosion control practices. Most activities fail to meet stormwater design standards theoretically required by US and PR Commonwealth regulations. The accelerated pace of development in Culebra, accompanied by an unwillingness to comply with or enforce environmental regulations by both the private and public sectors has led to increases in soil erosion and sediment delivery rates to the marine environment which have been implicated in documented coral reef decline (HernándezDelgado et al., 2006). We believe that Culebra is currently exhibiting its highest ever sediment yield levels as a result of its recent and ongoing construction activities, as it has been suggested elsewhere (Wolman, 1967; MacDonald et al., 1997; Brooks et al., 2007; Ryan et al., 2008). Limited background information currently exists on the type of land development on a sub- 
tropical dry climatic setting such as in Culebra, but data from similar sites in La Parguera (southwestern PR) and St. John (USVI) suggest that disturbed hillslopes can erode at rates that are ten to up to four-orders of magnitude higher than undisturbed, densely-vegetated surfaces (Ramos-Scharrón and MacDonald, 2005, 2007a; Ramos-Scharrón, 2010), and that current watershed-scale sediment yields into coastal waters are upwards to ten times higher than under undisturbed conditions (Ramos-Scharrón and MacDonald, 2007b).

\section{Methods}

The new assessment framework presented here follows a multi-step approach (Figure 3). The first step requires collecting the basic information to describe coral reef abundance and condition, estimating watershed-scale sediment loading rates, and evaluating the feasibility of on-site erosion control measure installation. The second step is meant to formalize an approach to select the watersheds and associated marine habitats that merit a preferred status for the implementation of erosion control activities [Section 3.4.1]. Evaluation of need to mitigate erosion is gaged based on three main considerations: (1) resource abundance- the amount of surface prone for coral reef growth and/or the abundance of particular coral species of concern [Section 3.1.1]; (2) resource condition- the observed condition of the coral

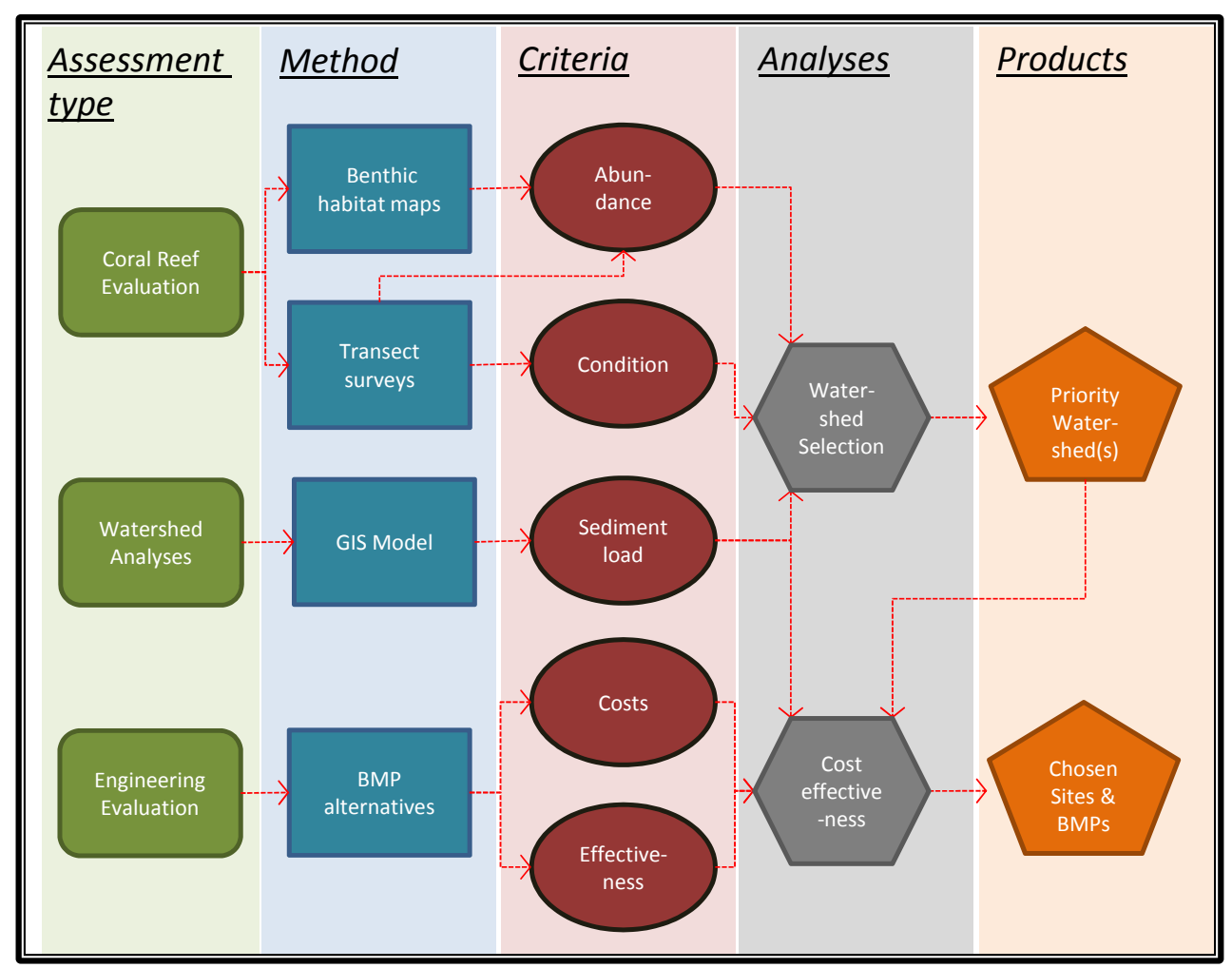

Fig. 3. Flowchart displaying the general scope of the proposed, interdisciplinary erosion mitigation strategy described here. 
reef ecosystem [Section 3.1.2]; and (3) stress level- sedimentation stress defined by annual sediment yields [Section 3.2]. The final step focuses on the selected watershed(s) and aids in choosing the specific sites (i.e., sediment sources) and methods to be implemented within the priority areas by invoking a sediment reduction cost-effectiveness analysis [Section 3.4.2]. The goal of this final analysis is to minimize the costs of BMP implementation [Section 3.3] while maximizing the reductions in sediment delivery.

Financial constrains will always pose limits to the level and extensiveness of erosion control programs. The guidelines presented here describe a conceptual framework to optimize the use of multi-disciplinary information concerning coral reef abundance and condition, sediment loading rates, and engineering considerations in defining priorities and solutions to tackle erosion control goals. The framework presented here has the potential for becoming incorporated in watershed management plans in other areas of PR and elsewhere throughout the Caribbean.

\subsection{Coral reef assessment}

\subsubsection{Abundance of coral reef habitats}

An analysis on the abundance of nearshore submerged zones prone for coral reef establishment and growth was based on its areal coverage, and relied upon pre-existing benthic habitat maps derived from aerial photo-interpretation of images taken in 1999 (NOAA-NOS, 2001). The NOAA-NOS map is publicly available as an ArcGIS shapefile and contains polygons organized following a hierarchical collapsing classification scheme. Classes ranged from eight generalized categories to twenty-six sub-classes that describe in increasing detail each habitat type (Kendall et al., 2001). Since our main intent was to quantify the area prone for coral reef growth, we opted to rely on the third tier of this classification scheme (database attribute: 'HABITAT') that delineates areas as 'coral reef and colonized hardbottom', 'submerged aquatic vegetation' (SAV), 'unconsolidated sediments', and 'others'. The original polygon geometry of the NOAA-NOS map was simplified by dissolving polygons based on the 'HABITAT' attribute.

The premier intention of the abundance analyses was to quantify the areal coverage of coral reef areas in the proximity of each of the eight watersheds of interest. Therefore, our procedure had to assign a submerged area to each of the watersheds. The submerged area for each location is roughly based on a $450 \mathrm{~m}$ buffer extending from the coastline defining the downslope end of all watersheds. The edges of each of the areas were manually edited to avoid overlaps whenever conflicts existed between two adjacent watersheds. Each of the newly created submerged area polygons were used to clip or extract the simplified benthic habitat map. The surface area for the clipped and simplified benthic habitat maps was calculated in hectares and summarized to provide a total area for the four 'HABITAT' categories within each of the submerged areas.

\subsubsection{Structure and condition}

Coral reef communities adjacent to the terrestrial study sites were assessed in 2007 using digital video imaging and six replicate $25 \mathrm{~m}$-long point-intercept line transects per site, with intersects at $0.5 \mathrm{~m}$ intervals $(\mathrm{n}=50$ points/transect). This protocol represents a slight modification from Rogers et al. (1994). Data was obtained at depths typically ranging from 3 
to $7 \mathrm{~m}$. Deeper reef zones were not assessed and consequently not included in the analysis. Data used for this study included percent cover of benthic components: live coral, macroalgae, algal turf, crustose coralline algae (CCA), and cyanobacteria. The data obtained also allowed calculations of live coral to algal ratios (i.e., 'coral:algal') for all algal functional groups, as well as coral to cyanobaterial ratios (i.e., 'coral:cyanobacterial'). Ratios are used to further describe the condition of the reef ecosystem. Addressing spatial patterns in algal communities is of utmost importance since they often respond relatively fast to runoff, eutrophication and sedimentation disturbance. Observed percent living coral cover values could be considered as either a measure of abundance or descriptive of existing conditions. The same could be said for the percent relative cover of four highly sensitive Scleractinian coral species: Elkhorn coral (Acropora palmata), Staghorn coral (A. cervicornis), Columnar star coral (Montastraea annularis), and Laminar star coral (M. faveolata).

\subsection{Watershed assessment}

The unpaved road network in Culebra is considered to be the island's most important anthropogenic source of sediment (Ramos-Scharrón, 2009; Figure 2). Therefore, our erosion and sediment yield assessments relied upon application of the STJ-EROS model (RamosScharrón, 2004; Ramos-Scharrón and MacDonald, 2007b) as it provides a modeling structure that estimates the annual sediment contribution from both natural sources of sediment and unpaved road networks. STJ-EROS is a Geographical Information System (GIS) model that uses empirical sediment production functions (Ramos-Scharrón, 2004; Ramos-Scharrón and MacDonald, 2005, 2007a) and sediment delivery ratios to estimate sediment yields into coastal waters. STJ-EROS estimates erosion rates from both natural (i.e., streambanks, treethrow, and undisturbed hillslopes) and anthropogenic sources of sediment (i.e., unpaved roads) based on empirical equations developed from data collected on St. John (U.S. Virgin Islands-USVI), an island with a similar physical setting as Culebra's. In STJ-EROS, the estimated sediment delivery rate from the terrestrial to the marine environment is controlled by user-defined sediment delivery ratios (SDRs), where SDR is the ratio of sediment delivered to the gross erosion occurring within the basin (Walling, 1983). STJ-EROS allows users to choose SDR values for areas having different delivery potentials defined by qualitative observations on the location of coastal wetlands relative to the stream network. Areas draining through wetlands before delivering runoff into coastal waters received a SDR value of $25 \%$, while those directly draining into coastlines without an intervening wetland were assigned a SDR of 75\% (Ramos-Scharrón, 2009). A $1000 \mathrm{~mm}$ per year rainfall value was consistently used for all eight watersheds.

Field surveys consisted in the preparation of input geo-databases required by STJ-EROS. Field reconnaissance determined that the algorithms for two of the natural sources of sediment included in STJ-EROS did not apply to the conditions in Culebra. Treethrow, or the generation of sediment by the uprooting of wind-thrown trees, was not considered relevant in Culebra given the generally low-lying, dry-forest type of vegetation of the island which contrasts with the wetter and taller, treethrow-prone trees found on higher elevation portions of St. John (Reilly, 1991). In addition, none of the watersheds of interest contained well-defined stream channel features from which streambank erosion could be expected. Therefore, the application of STJ-EROS in Culebra assumed that surface erosion from currently undisturbed hillslopes is the only natural source of sediment of significance on the island. 
Unpaved roads on Culebra were found to be similar to those from which the STJ-EROS road erosion algorithms were developed in terms of substrate, road prism geometry, and range of slopes. STJ-EROS requires building up a geographical database that involves mapping of individual road segments and their associated drainage points (i.e., culverts, water bars, etc.). Individual road segments were spatially delimited by changes in surface type (i.e., paved versus unpaved and assumed grading frequency) and they consist of road sections with flow patterns uninterrupted by drainage structures. Geographic and attribute data was generated by a combination of on-screen digitizing using an ortho-corrected, full-color, 1-m resolution, 2004 aerial image, in combination with field mapping using a Geographical Positioning Unit (GPS) and field sketches. Field sketches contained information related to surfacing (i.e., paved or unpaved), road segment geometry (i.e., length and width of subsegments) measured with a tape measure, slope in percent measured with a hand-held clinometer, and a categorical description related to the frequency of road grading (i.e., graded, ungraded, or abandoned-See definitions in Ramos-Scharrón and MacDonald, 2005). In the absence of precise time since construction or information on the frequency of grading, assigning a road segment to a category was based on a qualitative assessment of the road surface texture and vegetation cover. A road was identified as graded if its surface was dominated by a fine granular texture, limited exposure of large rock fragments, and low vegetation cover. Ungraded roads were those still actively travelled but with an abundance of coarse fragments (i.e., armored surface) and low to moderate vegetation cover density. Abandoned roads were those that exhibited an armored surface and a high abundance of vegetation due to scarce or no traffic.

The eight watersheds of interest covered a total area of $6.8 \mathrm{~km}^{2}$ or about a quarter of the total landmass of Culebra. Individual watersheds ranged in drainage areas from 9.1 ha at Punta Soldado (PSO) to 274 ha at Puerto Del Manglar (PDM) (Table 1). The proportion of area defined as having a high potential for sediment delivery varied widely from a maximum of $99 \%$ at PSO and Ensenada Fulladosa (EFU) to a minimum of $16-17 \%$ at the larger watersheds of PDM and Bahía Mosquito (BMO) that contain extensive wetland areas. The eight watersheds contain almost $35 \mathrm{~km}$ of roads out of which $24 \mathrm{~km}$ remain unpaved for an overall unpaved road density of $3.5 \mathrm{~km} \mathrm{~km}^{-2}$. About $24 \mathrm{~km}$ of roads were field-surveyed in 2008 within the eight watersheds. Data for road segments for which no access was allowed was estimated based on aerial image interpretation and GIS analyses. Roads that were not surveyed were assigned a standard $4.0 \mathrm{~m}$ width and assumed to be ungraded. Drainage points along these roads were presumed to be located at topographical depressions; slope was calculated using the digital elevation model by taking the elevation difference between the top and lower ends of the road segment and dividing it by the length of the segment. Runoff from all roads is delivered off the road network at 160 drainage points.

STJ-EROS calculates total sediment production (i.e., total erosion) from all individual road segments within a watershed as well as their estimated annual sediment yield contribution to coastal waters (i.e., sediment delivery in tons per year). Model results are of three main sorts. First, the model provides an estimate of the total amount of sediment delivered to the marine environment every year from any given watershed. Second, the model may isolate the contribution from each sediment source type (i.e., undisturbed hillslopes, and graded, ungraded, or abandoned unpaved roads), thus allowing us to rank sources according to their net contribution. Finally, the GIS nature of the model allows it to spatially display the 


\begin{tabular}{|c|c|c|c|c|c|c|}
\hline Watershed & $\begin{array}{l}\text { Drainage } \\
\text { area } \\
\text { (ha) }\end{array}$ & $\begin{array}{c}\text { Proportion } \\
\text { of Area } \\
\text { with High } \\
\text { SDR (\%) }\end{array}$ & $\begin{array}{c}\text { Proportion } \\
\text { of Area with } \\
\text { Moderate } \\
\text { SDR (\%) }\end{array}$ & $\begin{array}{c}\text { Total } \\
\text { roads } \\
(\mathbf{k m})\end{array}$ & $\begin{array}{c}\text { Unpaved } \\
\text { roads } \\
(\mathbf{k m})\end{array}$ & $\begin{array}{c}\text { Number of } \\
\text { drainage } \\
\text { points }\end{array}$ \\
\hline Punta Soldado (PSO) & 9.1 & $99 \%$ & $1 \%$ & 0.09 & 0.09 & 0 \\
\hline $\begin{array}{l}\text { Ensenada Malena } \\
\text { (EMA) }\end{array}$ & 18 & $60 \%$ & $40 \%$ & 0.52 & 0.52 & 7 \\
\hline Cayo Dakiti (CDA) & 44 & $41 \%$ & $59 \%$ & 1 & 0.31 & 6 \\
\hline $\begin{array}{l}\text { Bahia Mosquito } \\
\text { (BMO) }\end{array}$ & 132 & $17 \%$ & $83 \%$ & 7.4 & 5.3 & 34 \\
\hline $\begin{array}{l}\text { Ensenada Fulladosa } \\
\text { (EFU) }\end{array}$ & 70 & $99 \%$ & $1 \%$ & 6.9 & 4.5 & 42 \\
\hline $\begin{array}{l}\text { Puerto Del Manglar } \\
\text { (PDM) }\end{array}$ & 274 & $16 \%$ & $84 \%$ & 12.8 & 9.7 & 49 \\
\hline Playa Larga (PLA) & 52 & $78 \%$ & $22 \%$ & 2.1 & 1.8 & 8 \\
\hline Playa Zoni (PZO) & $\underline{81}$ & $28 \%$ & $72 \%$ & $\underline{3.9}$ & $\underline{1.9}$ & $\underline{14}$ \\
\hline Total & 680 & & & 34.7 & 24.1 & 160 \\
\hline
\end{tabular}

Table 1. Summary description of the eight study watersheds including their drainage areas, the proportion of each watershed contained within the two sediment delivery ratio (SDR) categories, the total length of roads and unpaved roads, and the number of road drainage points.

magnitude of sediment contributed by individual road segments or the amount of sediment being delivered from the road network to the marine environment through each individual drainage structure.

\subsection{Best Management Practices}

Best Management Practices (BMPs) related to soil erosion refer to "... a variety of site planning, design, and construction activities to minimize the production and transport of sediments" (Anderson, 1994). BMPs may refer to precautions taken during the planning and construction stages of new roads that help locate, align, and define their geometry by not only considering their capital costs but also taking into account potential contamination of downstream water bodies. It is our impression from the current state of the road network in Culebra that, with only few exceptions, no erosion control considerations are contemplated when roads are being planned and laid out. Since the intention of this article is to provide guidance on mitigating already existing problems, readers are referred elsewhere for a comprehensive discussion on forest road construction guidelines (e.g., B.C. Ministry of Forests, 2002).

Road erosion mitigation BMPs are of three main types. First, are those methods that improve the resistance to erosion processes by preventing the direct contact of rain and runoff with the soil surface (Type I). These include different methods to promote re-vegetation, use of gravel for added protection (Ziegler and Sutherland, 2006), and paving a surface with concrete. The 
second type of BMPs is meant to minimize the amount of flow on the unpaved road surface and thus reduce its erosive energy. This is mostly achieved by preventing flow concentration with a variety of stormwater drainage structures including side-ditches, rolling dips, water bars, and culverts, among others (Ramos-Scharrón, in press). The third type of BMP attempts to capture as much sediment as possible while runoff is transported through or discharged from the road prism (Type III). These BMPs reduce flow velocity and thus promote settling of sediment, and include methods such as hay bales, sediment traps, check dams, and settling ponds (Anderson, 1994). Road drainage improvements (Type II) may also be viewed as attempts to reduce the downstream transport of eroded sediment as adequate placement of road drainage structures also promotes reduced connectivity with downslope water bodies (Megahan and Ketcheson, 1996; Croke et al., 2005).

The specific approach to identifying erosion and sediment control BMPs in Culebra is framed by three general limitations including: (a) an already existing and thus mostly immovable road network layout; (b) a characteristically rugged topography, and (c) a lack of locally available specialized materials and equipment that significantly increases costs and therefore reduces the number of BMPs that would otherwise be considered feasible. The following list of BMPs consists of those methods that are being given further consideration for application in Culebra as they are deemed implementable from a technical and economical point of view:

i. Inside ditch- An upslope or inside ditch running along the length of the road reduces erosion by providing a surface specifically prepared to handle the runoff generated by the road travelway (Types I and II).

ii. Vegetated ditch-Allowing or providing for vegetative cover within ditches stabilizes the ditch surface, reduces flow energy and enhances suspended sediment deposition (Types I and II).

iii. Check dams- When installed along ditches, check dams reduce flow energy and thus reduce the potential for erosion. Dams also allow sufficient space for sediment deposition and can be constructed of locally available materials such as rocks, logs, or properly treated native soil (Types II and III).

iv. Rolling dips- These stormwater handling structures consist of a reverse grade depression aligned diagonally to the general trend of the road. A mound of soil running parallel to the downslope side of the dip serves to increase their runoff handling capacity. Rolling dips are used to divert water from the unpaved surface into the ditch or out of the road prism and therefore reduce flow concentration and shorten downstream delivery (Types II and III).

v. Paved gutter- These play a similar role to rolling dips in that they divert water into a ditch or out of erodible road surfaces. The only difference is that these are covered by pavement and are therefore more costly (Types I, II, and III).

vi. Energy dissipaters- These are installed at discharge points on the downslope end of the road prism. They usually consist of riprap, baffled concrete structures or small catchment basins. Implementation costs are low to high, depending on the type. For the purpose at hand we have considered riprap as the preferred energy dissipating BMP with a moderate implementation cost (Types I, II, and III).

vii. Wire-mesh pavement- This is a measure that makes the surface impervious and prevents contact between in-situ soil particles with rainfall and runoff. Implementation costs are very high. (Type I). 
BMP selection in most cases is site specific and a combination of these individual BMPs is usually the most effective alternative. Therefore, we developed three general road designs or treatments, each incorporating a different sub-set of BMPs (Table 2). The first type maintains an unpaved road segment, but enhances stormwater management by constructing a properly vegetated ditch with check dams, unpaved rolling dips, and energy dissipaters every $30 \mathrm{~m}$ (\$325 per linear meter of road). The second type exactly matches the first type description but relies on a paved gutter to channel water out of the road surface instead of a rolling dip $\left(\$ 350 \mathrm{~m}^{-1}\right)$. The third type refers to a fully-paved road with an adequately vegetated ditch, no check dams, and one paved gutter every $30 \mathrm{~m}$ with an accompanying energy dissipater $\left(\$ 600-\$ 650 \mathrm{~m}^{-1}\right)$. Post-implementation erosion rates for the two treatments that maintain an unpaved road surface is estimated to be $30 \%$ of pretreatment rates and this is based on an effectiveness evaluation study conducted for a singular road segment on St. John (USVI) (Ramos-Scharrón, in press). Erosion rates following treatment by paving the entire road travelway is expected to reduce rates to only about $10 \%$ of pre-treatment levels. This is based on field data collected from twenty road segments on St. John which found out that only $10 \%$ of the sediment exiting a road prism is generated by road cutslopes, while the remaining $90 \%$ of sediment is generated from the road travelway (Ramos-Scharrón and MacDonald, 2007a). Since pavement effectively shuts down the entire contribution from the road travelway, we assume that road cutslopes are the sole source of sediment exiting the road prism. It is important to note that our effectiveness evaluations cannot estimate the role played by the check dams or energy dissipaters in reducing sediment production rates.

\begin{tabular}{|c|c|c|c|c|c|c|c|c|c|}
\hline $\begin{array}{l}\text { Treat- } \\
\text { ment } \\
\text { name }\end{array}$ & $\begin{array}{l}\text { Inside } \\
\text { ditch }\end{array}$ & $\begin{array}{l}\text { Vegetated } \\
\text { ditch }\end{array}$ & $\begin{array}{l}\text { Check } \\
\text { dams }\end{array}$ & $\begin{array}{c}\text { Rolling } \\
\text { dips }\end{array}$ & $\begin{array}{l}\text { Paved } \\
\text { gutter }\end{array}$ & $\begin{array}{c}\text { Energy } \\
\text { dissipater }\end{array}$ & $\begin{array}{l}\text { Wire- } \\
\text { mesh } \\
\text { pave- } \\
\text { ment }\end{array}$ & $\begin{array}{l}\text { Costs } \\
\text { (U.S. \$ } \\
\text { per m) }\end{array}$ & $\begin{array}{l}\text { Post- } \\
\text { treat- } \\
\text { ment } \\
\text { erosion } \\
\text { rates }\end{array}$ \\
\hline $\begin{array}{l}\text { Unpaved } \\
\text { with } \\
\text { rolling } \\
\text { dips }\end{array}$ & $\checkmark$ & $\checkmark$ & $\checkmark$ & $\checkmark$ & & $\checkmark$ & & $\$ 325$ & $\sim 30 \%$ \\
\hline $\begin{array}{l}\text { Unpaved } \\
\text { with } \\
\text { paved } \\
\text { gutter }\end{array}$ & $\checkmark$ & $\checkmark$ & $\checkmark$ & & $\checkmark$ & $\checkmark$ & & $\$ 350$ & $\sim 30 \%$ \\
\hline $\begin{array}{l}\text { Paved } \\
\text { with } \\
\text { gutter }\end{array}$ & $\checkmark$ & $\checkmark$ & & & $\checkmark$ & $\checkmark$ & $\checkmark$ & $\begin{array}{l}\$ 600- \\
\$ 650\end{array}$ & $\sim 10 \%$ \\
\hline
\end{tabular}

Table 2. Summary of the three main treatment types being considered for implementation in Culebra. Each treatment contains a different assortment of BMPs. Costs represent implementation costs in Culebra in U.S. dollars and apply to 2011 prices; efficiency of the different treatment options are based on the road erosion literature. 


\subsection{Prioritization strategy}

Ecological restoration implies the manipulation of an ecosystem with the purpose of returning it back to its 'pristine' condition (Bradshaw, 1997). The approach proposed here recognizes the impracticality of attempting to fulfill the goal implied by this strict definition of restoration. The inadequacy of setting such rigorous goals is particularly applicable to coral reefs as they represent open systems affected by diverse biotic and abiotic processes, some of which act at spatio-temporal scales that are inalterable by direct human intervention. In addition, it is questionable if truly pristine coral reefs that could represent a genuine 'reference state' still exist in the Caribbean (Jackson, 1997, 2001; Gardner et al., 2003; Hawkins and Roberts, 2004). Therefore, we propose that an achievable goal of erosion control strategies should be simply to mitigate the effects of land erosion and sediment yields into coral reef systems, where mitigation "...refers to activities that lessen the degree of damage to an ecosystem..." (Jackson et al., 1995). Hence, erosion mitigation by itself has the singular purpose of reducing sediment delivery to levels that are somewhat closer to background rates. The presently grim condition of most coral reefs in the Caribbean and in Culebra is sufficient to justify curtailing sediment delivery into any reef-bearing water body (Hernández-Delgado, 2010; Hernández-Pacheco et al., 2011). Unfortunately, funding limitations will always restrain the level and extensiveness of erosion control strategies. Therefore, a scientifically-sound process by which priority areas for erosion control are selected based on local observations, needs, and availability of funds is critical to maximize the benefits of the effort, as well as to ensure goals and expectations are clearly acknowledged, and that activities are in agreement with the intended results.

The analyses presented here are limited in two important ways. First is that the coral reef condition assessments are based on a single, one-time observation. Therefore, the procedure is blind to trends in coral conditions that could serve in making more sound judgments when setting priorities for erosion control efforts. Second is that the erosion analyses explicitly lacks the capacity to understand sediment dynamics and effects once delivered to the marine environment. We acknowledge that an annual estimate of sediment delivery is too coarse to provide the temporal resolution needed to follow a process-based examination of the role of sediments on reefs. Nevertheless, erosion mitigation as defined above does not require a priori diagnosis of sedimentation as the cause of any coral deterioration. By reducing sediment loads we can expect to alleviate the light transmissivity limitations, high nutrient concentrations, abrasion, and direct sedimentation stresses on coral reefs that ensue increases in land erosion (Fabricius, 2005). Diminishing sediment stress should benefit reef ecosystems directly by lessening these effects and indirectly by allowing corals to better cope with other sources of stress (Hoegh-Guldberg et al., 2007).

\subsubsection{Watershed selection}

The combined watershed and marine habitat evaluation procedure presented here is based on three criteria: (1) abundance of the marine resource (i.e., coral reefs) [Section 3.1.1], (2) marine resource condition [Section 3.1.2], and (3) stress level (i.e., sediment load) [Section 3.2]. This type of multi-parameter evaluation is expected to be applicable to relatively homogeneous areas that might have shared similar marine and terrestrial conditions during their pristine states. A contained area like Culebra provides the perfect scenario for this type of analyses as it holds coral reef ecosystems that are quite compatible in their structure, and 
where factors that control sediment yields, such as rainfall, soils, relief, and watershed size are comparable among different sites. The areas chosen in Culebra all lie outside of the 'special' marine areas of the island that include the former US NAVY training grounds and the CLPN Reserve.

Each of the three criterion being considered for analyses can be graphically portrayed as the axis of a three-dimensional cube in which sediment stress level is displayed along the $x-$ horizontal axis from low to high (left to right), while resource abundance is graphed in the y-vertical axis from low upwards to high abundance. Meanwhile, resource condition lies along the z-depth axis from good to poor (foreground to background) (Figure 4). The range of parameter values represented by each of the three axes making up the cube should represent the range of values found within the areas of interest. Therefore, the cube provides a conceptual space in which each of the areas is compared in terms of quantity and condition of coral reefs and sediment loading stress against the entire population of sites being considered and not to a theoretical reference state. Low/high and poor/good labels consequently refer to relative conditions within the context of the area of interest.

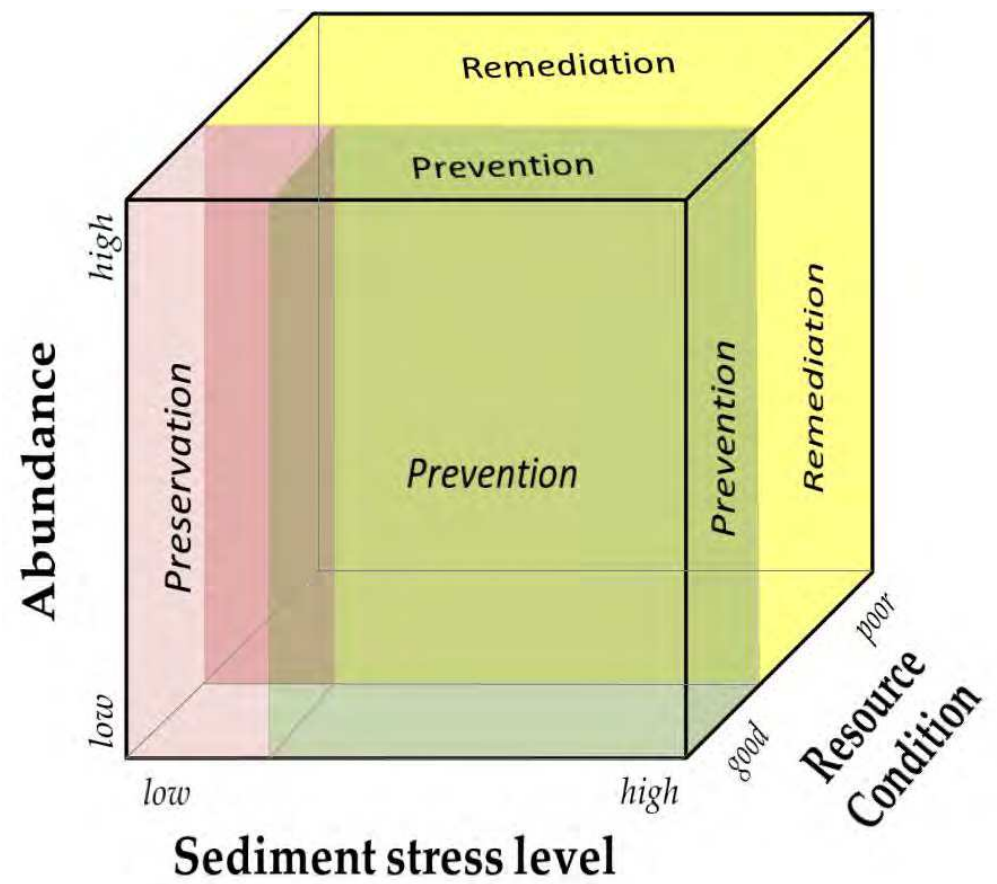

Fig. 4. This cube represents the conceptual model for evaluating the need for erosion mitigation in individual watersheds based on a set of multi-disciplinary parameters. The model is based on (a) abundance of marine areas prone for coral reef growth, (b) an assessment of coral reef condition, and (c) the estimated level of sediment stress originating from the most proximate watershed. Justification for controlling erosion varies according the particular values defined for the marine resource of interest and the watershed directly draining runoff and sediment into it. 
The cube may also serve as a graphical aid to guide or understand the management tendencies of conceding some areas with a priority status ranking in relation to others. As mentioned above, all erosion mitigation strategies on watersheds contributing sediments into reef-bearing waters of the Caribbean is likely justifiable but the resource conservation goal of implementing such strategies at each site depends on the existing conditions. Hence, the cube also serves to map the justification or goal of erosion control activities being implemented. Implementation of erosion mitigation strategies for coral reef protection can be justified on the basis of three main motives:

i. Preservation- Within the context of the framework being presented here, preservation implies that current coral reef and sediment loading conditions remain close to a 'pristine' or 'desired' state. That is, coral reefs are in good condition and sediment loading rates are low. Any mitigation activities taken in these areas are meant to maintain conditions in their current state.

ii. Prevention- This term implies safeguarding or taking actions that anticipate an imminent or potential problem. Erosion control efforts in areas characterized by moderate to good coral reef conditions and moderate to high sediment loads could be considered as preventive measures intended to avoid further coral reef deterioration.

iii. Remediation- Remediation implies reducing the level of stress to an ecosystem without any concern to an ultimate goal (Bradshaw, 1997; Clark, 1997). In this context remediation is very similar to the meaning attached to rehabilitation in which it implies activities meant to improve conditions on a coral reef with a presently degraded state with an emphasis on the process and not on the end point (Bradshaw, 2002).

Within the context of Figure 4 remediation applies to areas with moderate to poor coral reef conditions regardless of sediment stress levels. Remediation is a term we prefer over restoration as it lacks the intention of attempting to reverse conditions back to a pristine state. The approach presented here finds unnecessary to establish a diagnostic cause and effect relationship between high sediment loads and poor coral reef conditions. It simply acknowledges that any increase in sediment yield rates above background levels is potentially harmful to corals, and therefore any reductions in sediment delivery rates will be of benefit to reef ecosystems. Erosion control in the spirit of preservation, prevention, or remediation would then be assumed as a way to alleviate a source of stress related to sediments with the intention of improving the chances at handling other stressors. In other words, erosion mitigation can then be viewed as an attempt to "... restore self-healing processes in an ecosystem that will lead to balance once more." (Jackson et al., 1995). In addition, erosion control would also aid in establishing adequate conditions for enhancing the success of other management measures such as coral farming and transplanting.

Given the limitations imposed by the current state of coral reef science and the diversity of real-world scenarios we believe it to be unbeneficial to attempt to provide a simple generic formula to rank watersheds in terms of need or expected optimization of results. The final decision on prioritization must be left to stakeholders, managers, scientists, and engineers knowledgeable of the local conditions. Other criteria, such as physical connectivity between watersheds and marine resources outside the immediate receiving bays, the presence of areas or species with a special conservation designation, temporal trends in coral abundance or condition, and recent land development activities must also be considered. Nevertheless, 
the framework might be able to offer some explicit prioritization guidance in two special scenarios. One scenario is when two or more sites display similar coral and sediment load conditions, in which case priority could be awarded to areas with a higher abundance of reefs. A second scenario is one in which multiple sites possess similar reef abundance and coral conditions, in which case priority could be conceded to areas exhibiting the highest sediment loads.

\subsubsection{Site and BMP selection, cost-effectiveness analyses}

For the purposes of erosion mitigation, cost-effectiveness may be defined by the total amount of funds spent installing BMPs relative to the amount of sediment that will no longer reach coastal waters (i.e., sediment 'savings') as a result of their implementation. Therefore, cost-effectiveness for the case in Culebra will be described in terms U.S. Dollars spent on BMPs per ton of sediment 'saved' (\$ ton $\left.{ }^{-1}\right)$. Costs of the implementation of the unpaved road BMPs being considered in Culebra and their expected reductions in sediment production have been discussed above [Section 3.3]. Savings in the amount of sediment that would not be reaching the marine environment due to BMP installation are based in relation to STJ-EROS results and standard effectiveness measures. Cost-effectiveness evaluation was executed for only one of the eight study watersheds and consisted in the evaluation of per unit ton costs for treating road segments within the chosen watershed. Analyses were based on the three treatment options described in Table 2. Individual segments were ranked according to their pre-treatment sediment contribution and the cumulative implementation costs and sediment savings were calculated based on the incremental costs and 'savings' based on this ranking.

The cost-effectiveness analysis described here does not prescribe a given level of sediment reduction; it only attempts to maximize effectiveness given a total amount of funds available for mitigation. Coral reef science currently lacks the type of process-based analyses capabilities to define adequate loading levels. Levels that would suit a particular case might not be proper for another location due to differences in coral reef structure, species composition, or oceanographic conditions, to name a few. As previously described, our approach is based on the principle that any attempt to bring sediment loading levels closer to background rates is beneficial to coral reefs.

\section{Results, discussion and recommendations}

\subsection{Coral reef abundance}

The GIS procedure used to describe the benthic habitats directly linked to each of the eight study watersheds led to the characterization of 705 ha of submerged areas (Box 1). Almost $40 \%$ or 281 ha was identified as coral reef and colonized hardbottom, while $46 \%$ (325 ha) was SAV, and 14\% (99 ha) was unconsolidated sediments, algal plains or other delineations. The watersheds directly associated with the largest coral reef and colonized hardbottom areas were Playa Larga (PLA; 88 ha) and Puerto del Manglar (PDM; 58 ha). Meanwhile, Ensenada Fulladosa (EFU) contains no corals and is dominated by SAV, mostly extensive seagrass beds largely composed by Turtle grass (Thalassia testudinum) and manatee grass (Syringodium filiforme) (Hernández-Delgado et al., 2003). 


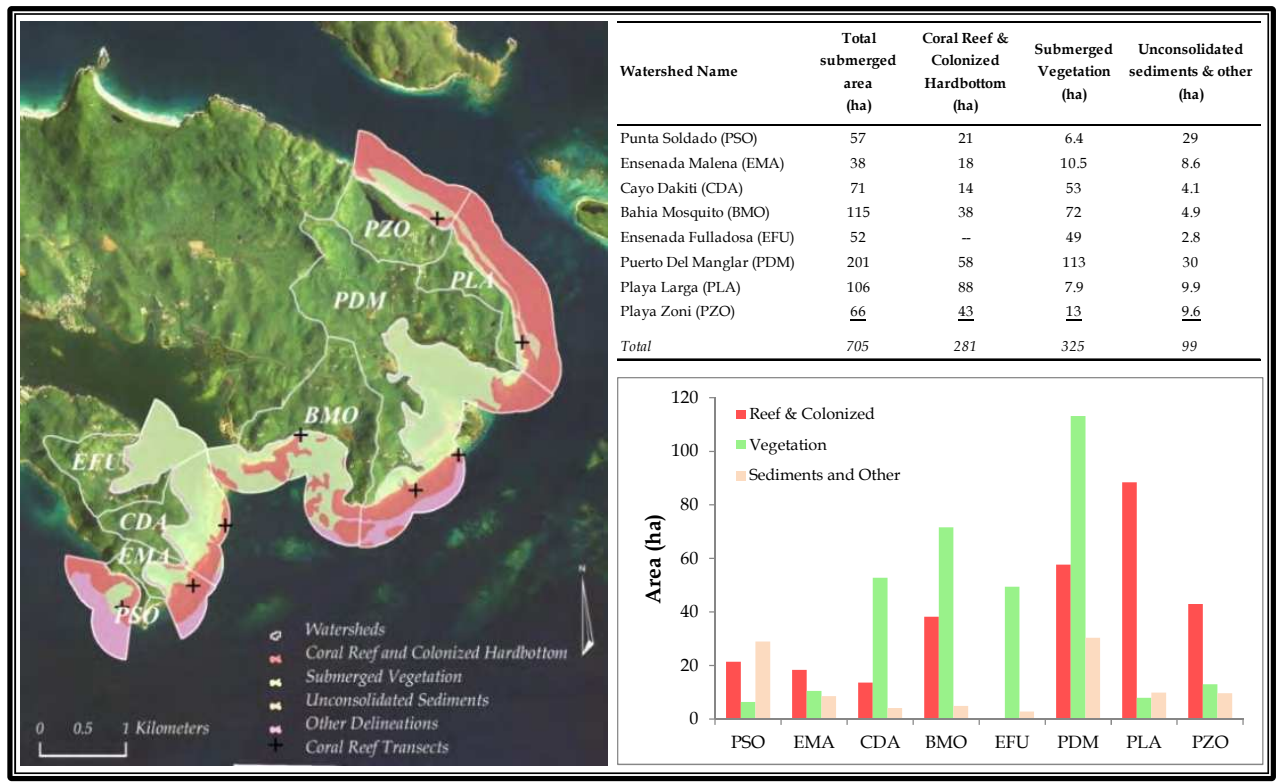

Box 1. Map of focus study area showing the code name and location of the eight study watersheds and the spatial distribution of benthic habitats directly associated to them. The table and figure summarize the quantitative benthic habitat abundance information obtained from the GIS analyses.

\subsection{Coral reef condition}

Benthic habitat characterization on coral reef communities adjacent to the study sites shows the unequivocal signs of long-term ecological decline. Overall, percent living coral cover averaged $7.8 \%$ across all study sites and was highest at Playa Larga (PLA) and Playa Zoní (PZO), with $12 \%$ and $10 \%$, respectively (Figure $5 \mathrm{a}$ ). The lowest percent living coral cover was observed at Bahía Mosquito (BMO) and at Cayo Dákity (CDA), with $4 \%$ and 3\%, respectively Columnar star coral (Montastraea annularis) had a mean $1.4 \%$ relative cover across all sites, with a maximum value of $2.7 \%$ at PLA and a minimum value of $0.2 \%$ at BMO and CDA. Laminar star coral (M. faveolata) had a mean relative cover of $0.24 \%$ across all sites, with a maximum value of $0.6 \%$ at Ensenada Almodóvar within Puerto Del Manglar (PDM-1). Star coral was absent from surveyed transects at BMO and CDA. Threatened Elkhorn coral (Acropora palmata) had a mean relative cover of $0.1 \%$ across all sites, with a maximum value of $0.3 \%$ at PLA. Elkhorn coral was absent from surveyed transects at Punta Soldado (PSO), Las Pelás (PDM-2), and CDA. Also, threatened Staghorn coral (A. cervicornis) had a mean $0.5 \%$ relative cover across all sites, with a maximum value of $3.6 \%$ at PLA. It was absent from surveyed transects at Ensenada Malena (EMA), CDA, BMO, and PZO. It should be noted that numerous areas were covered by dead colonies in standing position of each species at each site, particularly of Montastraea spp. and of A. palmata. Montastraea annularis and $M$. faveolata are dominant components of many coral reefs across the region, even reaching percent relative cover values of 40 to $50 \%$ of the coralline fauna at many sites, but have showed significant recent declines as a result of sediment-laden and nutrient- 
loaded runoff pulses, in combination with climate-related impacts (Hernández-Delgado, 2010; Hernández-Pacheco et al., 2011).
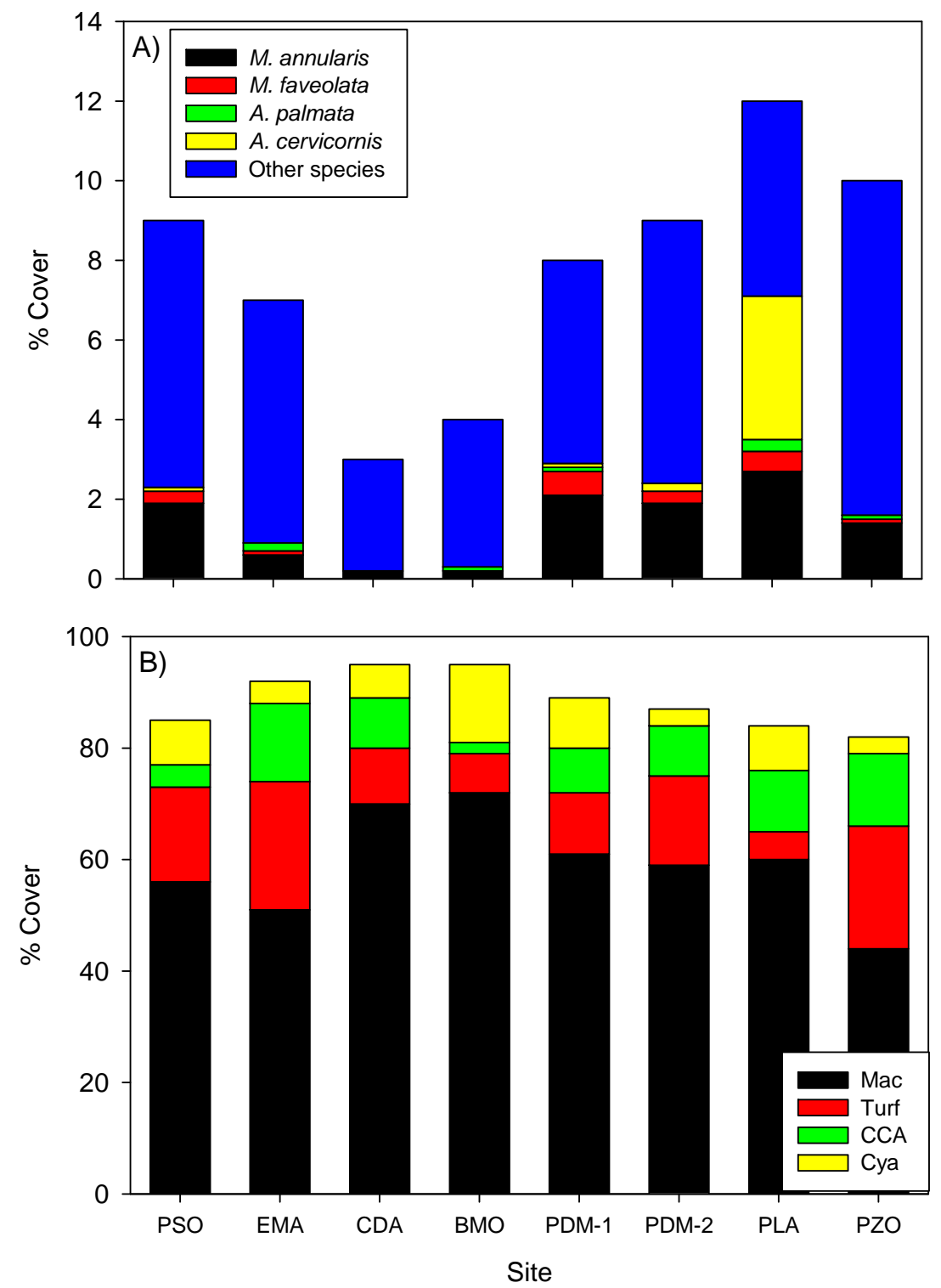

Fig. 5. Mean coral reef benthic parameter values for the eight study sites in Culebra. From top: A) Percent coral cover of four of the most sensitive Scleractinian coral species (M. annularis, M. faveolata, A. palmata, A. cervicornis); B) Percent cover of the four most important algal functional groups: macroalgae (Mac), turf, crustose coralline algae (CCA), and cyanobacteria (Cya). 
Benthic habitats were largely dominated by non-reef building taxa, mostly algae (Figure $5 b$ ). Macroalgae averaged 59\% across all sites and was particularly dominant on coral reefs adjacent to watersheds with higher sediment delivery rates like BMO (72\%). Unpalatable brown algae Dyctiota spp. and Lobophora variegata were dominant across all sites, with other
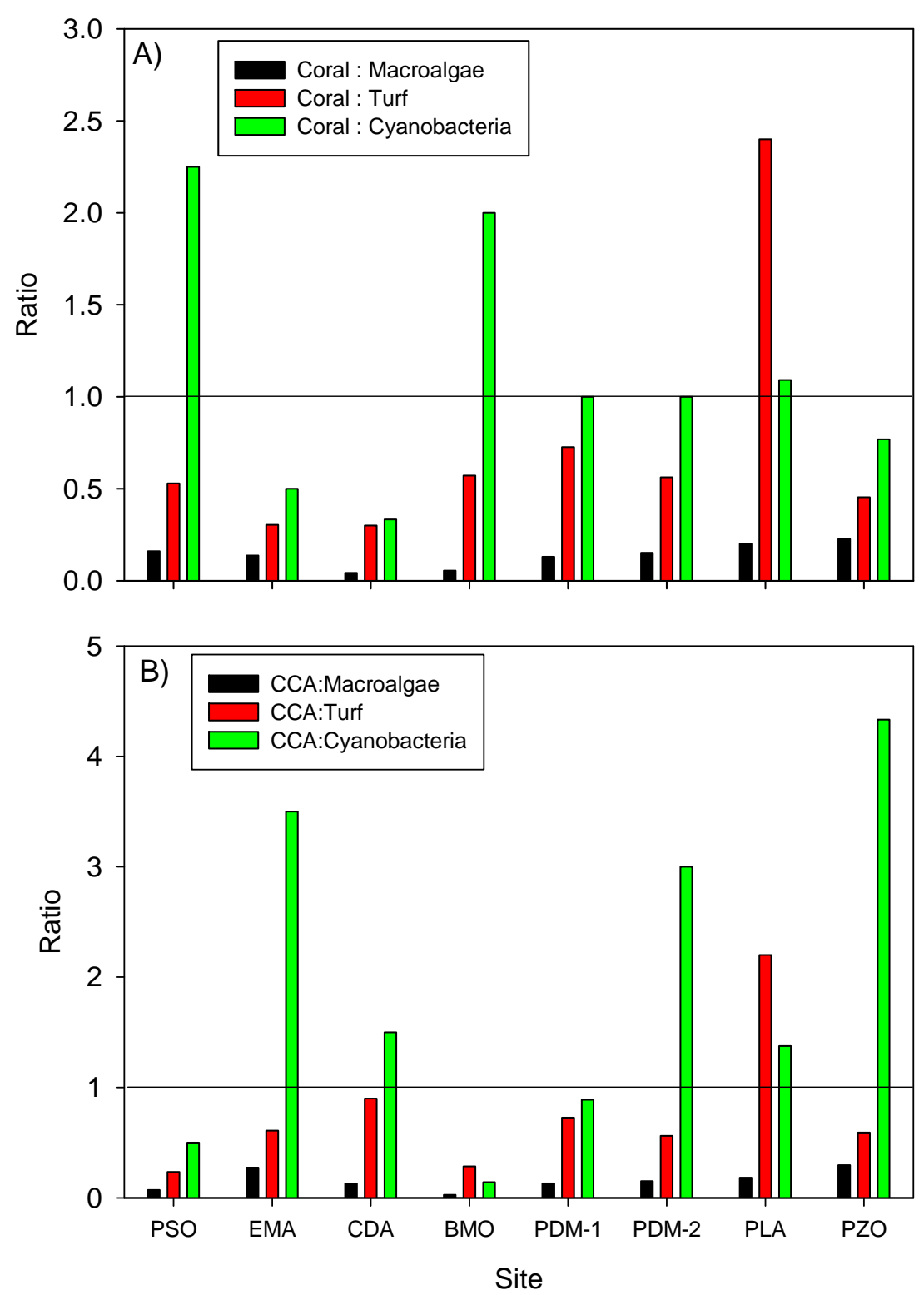

Fig. 6. 'Coral : algal' ratios (Figure 6a) and 'CCA : algal' ratios (Figure 6b) across the eight study sites in Culebra. 
red and green macroalgae that were locally abundant at CDA and BMO. Lowest macroalgal cover was documented at EMA (51\%) and PZO (44\%). Algal turf was the second abundant algal functional group (14\%), with higher values at EMA (23\%) and PZO (22\%), and lower values at PLA (5\%) and BMO (7\%). Crustose coralline algae (CCA) had a $9 \%$ mean cover across all sites, with maximum values at EMA (14\%) and PZO (13\%). The minimum value was observed at BMO (2\%). Finally, cyanobacteria showed a nearly $7 \%$ cover across sites, with the highest value at BMO (14\%), and the lowest at PDM and PZO (3\%).

The 'coral : macroalgae' ratio was highest at PZO (0.23) indicating a higher abundance of coral relative to other sites but still representing a macroalgae-dominated system. This ratio had its lowest value at CDA (0.04) (Figure 6a). The 'coral : turf ratio was highest at PLA (2.40), and lowest at CDA (0.30), while the 'coral : cyanobacteria' ratio was highest at PSO (2.25), and lowest at CDA (0.33). The 'CCA : macroalgae' ratio was highest at PZO (0.30), and lowest at BMO (0.03) (Figure 6b). The 'CCA : turf' ratio was highest at PLA (2.20), and lowest at BMO (0.29), while the 'CCA : cyanobacteria' ratio was highest at PSO (4.33), and lowest at BMO (0.14). Low 'coral : macroalgae' and 'CCA : macroalgae' ratios dominant across most sites, as well as the consistent abundant presence of cyanobacteria, strongly suggest that coral reef benthic communities across most sediment- and nutrient-impacted sites are being dominated by non-reef building taxa. Macroalgae, cyanobacteria, and other non-reef building taxa are known to be principal components of highly disturbed reefs, including those impacted by recurrent nutrient pulses (Cloern, 2001), sewage (Pastorok and Bilyard, 1985), low herbivory due to long-term fishing impacts (Bellwood et al., 2004; Hawkins and Roberts, 2004), or a combination of these (Littler et al., 2006a,b; Hernández-Delgado, 2010; Hernández-Delgado et al., 2010).

\subsection{Watershed assessment}

According to STJ-EROS, natural sources of sediment from within the eight study watersheds contribute 2.6 tons of sediment every year to the coastal waters of Culebra (Box 2). This estimate translates into an area-normalized yield rate of 0.40 tons $\mathrm{km}^{-2} \mathrm{yr}^{-1}$, which is an order of magnitude lower than the $2.6-6.7$ tons $\mathrm{km}^{-2} \mathrm{yr}^{-1}$ estimated for three watersheds on the island of St. John, U.S.V.I (Ramos-Scharrón, 2004). The difference between these rates is due to the lack of any sediment contribution from treethrow and streambank erosion in Culebra, two important sources of sediment dominating sediment delivery rates under natural conditions in St. John (Ramos-Scharrón and MacDonald, 2007a). STJ-EROS estimated that the total contribution from the unpaved road network in the eight study areas in Culebra is 347 tons per year or 133 times higher than background rates, and that the sediment gets distributed by a total of 160 road drainage points spread throughout the entire area (Box 2). Current sediment yield rates including contributions from both undisturbed hillslopes and the unpaved road network from all eight watersheds are estimated at $37.3 \mathrm{t} \mathrm{yr}^{-1}\left(5.6 \mathrm{t} \mathrm{km}^{-2} \mathrm{yr}^{-1}\right)$.

STJ-EROS estimated very variable sediment yields for individual watersheds (Box 2). On one extreme, PSO represents an area lacking direct anthropogenic impacts in that it contains no road drainage points and where the entire $0.06 \mathrm{t} \mathrm{y}^{-1}$ contribution is solely derived from undisturbed hillslopes. Similarly, the watershed directly fronting CDA represents a barely impacted area with sediment yield rates only slightly above undisturbed conditions due to the reduced length of unpaved roads (Table 1). EMA, BMO, PLA, and PZO represent intermediate 
disturbance conditions with a more highly significant presence of unpaved roads leading to sediment yield rates ranging from 10.7 to 46.4 tons $\mathrm{yr}^{-1}$. Meanwhile, EFU and PDM represent areas with extremely high sediment delivery rates of 112 and 154 tons $\mathrm{yr}^{-1}$, respectively. The high delivery rates for EFU and PDM are due to the presence of a dense unpaved steep road network and road conditions that are prone to high road sediment production rates (i.e., steeper slopes and abundance of frequently graded roads). In addition, for the particular case of EFU the high delivery rates are also due to the lack of a prominent wetland buffer area that could promote the settling of sediment before it enters the bay. Although EFU does not support coral reef ecosystems, it did have a direct and rapid oceanographic connectivity with CDA, and with BMO in a lesser degree, particularly during ebbing tides. Normalized sediment yield rates for individual watersheds ranged between 0.68 and 220 tons $\mathrm{km}^{-2} \mathrm{yr}^{-1}$, which expand beyond the 8-46 tons $\mathrm{km}^{-2} \mathrm{yr}^{-1}$ rates estimated for three watersheds on St. John (Ramos-Scharrón and MacDonald, 2007b). While the lower rates in Culebra represent rates equal to background conditions, the upper range of these rates represent delivery rates that are up to 320 times higher than background levels.

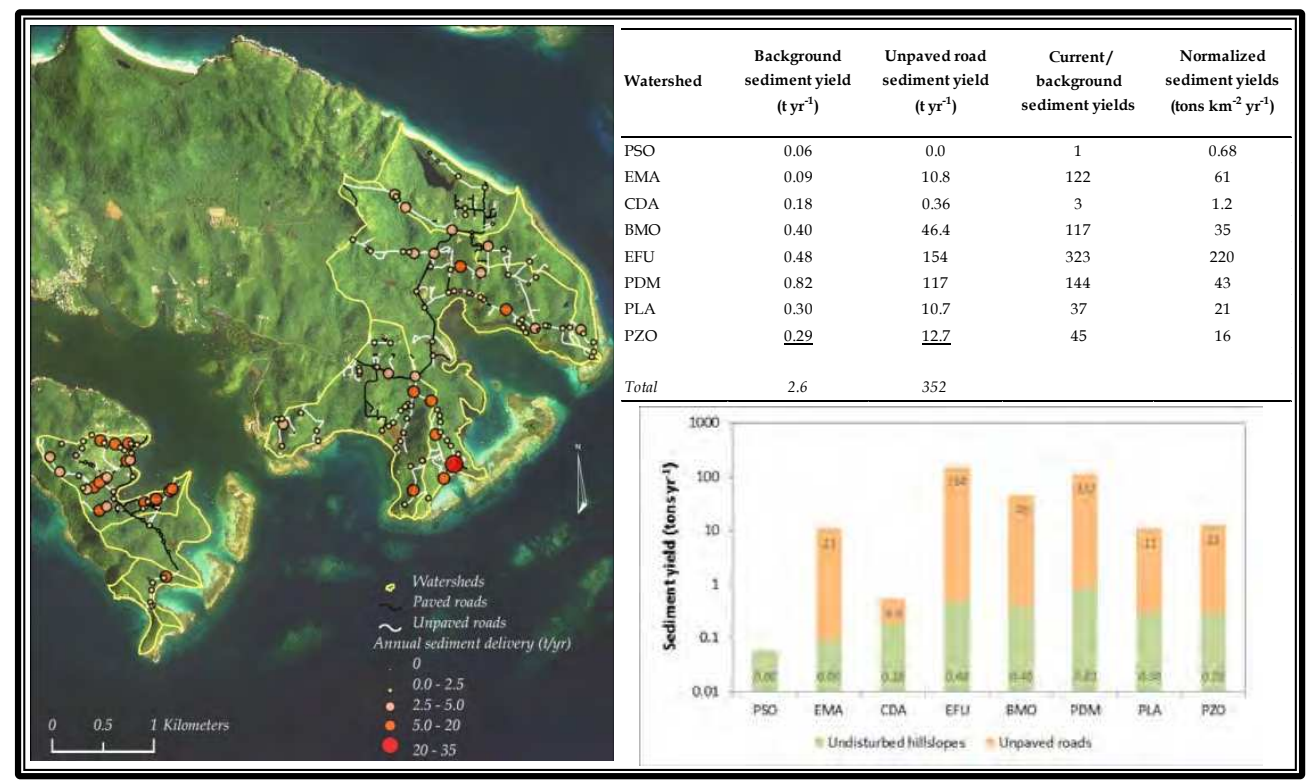

Box 2. Map presents one option for geographically displaying the STJ-EROS model results. Points in the map represent the annual amount of unpaved road sediment reaching a particular road drainage structure within the eight study watersheds. The table and figure summarize the estimated sediment yield rates related to both natural undisturbed hillslopes and the unpaved road network according to STJ-EROS.

\subsection{Watershed-marine habitat selection}

Watershed size and sediment delivery potential, as well as the length and characteristics of the unpaved road network have a direct influence on anthropogenic-driven sediment yield, which in turn impact adjacent coral reef ecosystems. Larger watersheds having a 

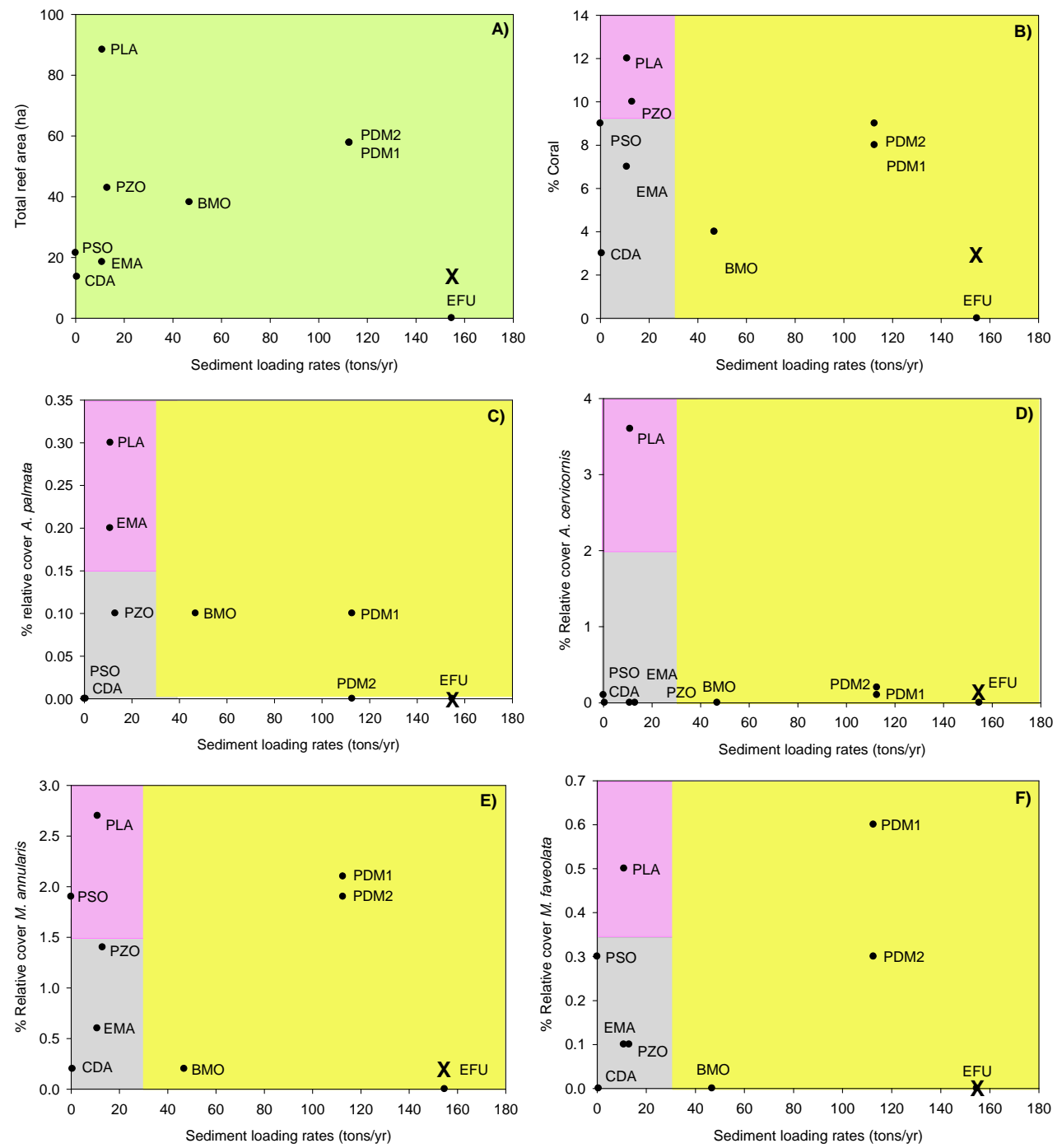

Fig. 7. Relationship between sediment loading rates and several benthic parameters across impacted coral reefs in Culebra: A) Total reef area; B) Percent living coral cover; C) Percent relative cover of Staghorn coral (Acropora cervicornis); D) Percent relative cover of Elkhorn coral (A. palmata); E) Percent relative cover of Columnar star coral (Montastraea annularis); and F) Percent relative cover of Laminar star coral (M. faveolata). Colors represent the justification for erosion control actions as follows: Yellow= remediation; Gray= prevention; and Pink= preservation as indicated in Figure 4. Point ' $X$ ' denotes a more realistic condition for CDA due to its down current oceanographic connectivity with EFU and the rest of Ensenada Honda (Figure 1). 

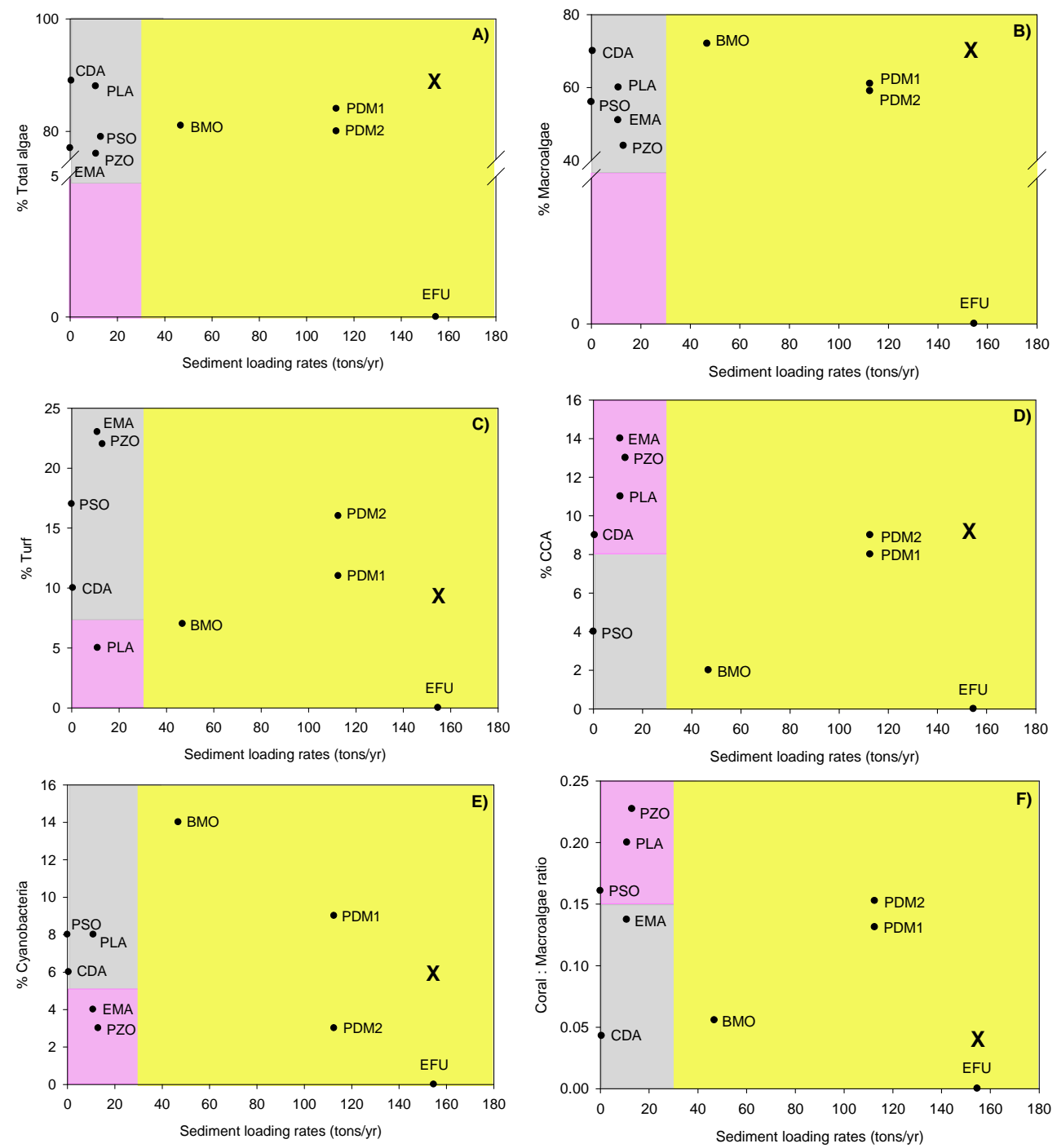

Fig. 8. Relationship between sediment loading rates and several benthic parameters across impacted coral reefs in Culebra: A) Percent total algal cover; B) Percent macroalgal cover; C) Percent algal turf cover; D) Percent crustose coralline algae (CCA) cover; E) Percent cyanobacterial cover; and F) Coral : Macroalgae ratio. Colors represent the justification for erosion control actions as follows: Yellow= remediation; Gray= prevention; and Pink= preservation as indicated in Figure 4. Point ' $X$ ' denotes a more realistic condition for CDA due to its down current oceanographic connectivity with EFU and the rest of Ensenada Honda (Figure 1). 
higher density of steep unpaved and graded roads showed the highest sediment delivery rates to adjacent waters, often impacting large coral reef areas (Box 2; Figure 7a). For example, PDM and BMO both represent large areas generating high sediment yields and associated reef systems with parameters that mostly place them within what would be considered impacted reef systems (i.e., low to moderate coral cover, high algal coverage, and low to moderate coral to macroalgae ratios, among others) (Figures 7b-7f, 8a-8f). Therefore, support for selecting these two areas as priority sites for the implementation of erosion control measures could be justified as attempts to 'remediate' impacted systems. In contrast, small drainage areas like PSO, EMA, PLA, and PZO yield sediments at very low rates and each is associated with reefs that could be considered in good to moderate condition relative to all other study sites (i.e., moderate to high coral cover, a relatively high abundance of Staghorn, Elkhorn, Columnar, and Laminar star coral, low to high algal coverage, and high coral to macroalgal ratio) (Figures 7b-7f, 8a-8f). Support for erosion control on these watersheds could be catalogued as a 'preventive' effort. No erosion control efforts within the eight study areas could be considered to be in the spirit of 'preservation' due to the general poor condition of the reefs.

Two areas that merit to be analyzed in more detail with respect to their sediment loads and coral conditions are EFU and CDA. EFU consists of a moderately-sized area with a high abundance of unpaved roads and it represents the highest estimated sediment delivery rates among all study areas (Box 2). Meanwhile, CDA consists of a small drainage area with very little sediment yields and a marine environment with a very low coral cover and an abundance of macroalgae (Box 2, Figures 7b, 8b). The marine habitat directly connected to EFU consists of an important submerged aquatic vegetation area, therefore no argument for erosion control could be justified based on a strict interpretation of our scheme that only considers the abundance and condition of the immediately adjacent reef systems. We argue that erosion control in the EFU watershed could be justified based on the argument that marine systems are interconnected through complex ecological functionalities so that benefits to a SAV-dominated area could also serve to improve conditions on nearby reef areas. In the particular case of EFU, anecdotal evidence indicates that the sediment plume that flows out of the EFU marine area directly affects the impacted CDA reef system (Hernández-Delgado, pers. obs.). Therefore, erosion mitigation at EFU could be justified in terms of both preserving the SVA area at EFU and in remediating the adjacent reef systems at CDA. The interconnectivity between EFU and CDA, and between Ensenada Honda and all of its encompassing bays (Figure 1), signals the value of cumulative environmental impacts and anecdotal information in making final decisions for prioritizing erosion control efforts and the potential for incorporating other factors such as oceanographic current patterns in our analyses.

\subsection{Site and BMP selection}

The PDM watershed was chosen as the target area for conducting cost-effectiveness analyses because of its high sediment yield rates, its relatively extensive unpaved road network, and the poor to moderate condition of its adjacent marine resources. PDM contains a total of 9.4 $\mathrm{km}$ of unpaved roads, sub-divided into 104 individual road segments which in total deliver 112 tons of sediment every year into the receiving coastal waters (Box 2). The average road segment has a length of $90 \mathrm{~m}$ and a slope of $7 \%$ with individual values ranging between 12 - 
$390 \mathrm{~m}$ and from $0 \%$ to $25 \%$, respectively. Twenty-seven road segments individually contribute more than 0.82 tons $\mathrm{yr}^{-1}$, which is the estimated background sediment yield level for this watershed (Box 3). Although these road segments represent only $36 \%$ of the total unpaved road network and approximately $0.6 \%$ of the entire watershed surface area $(\sim 1.6$ ha), they are responsible for $86 \%$ of its sediment yield. Three segments encompassing 0.74 $\mathrm{km}$ of roads individually contribute an excess of 10 tons of sediment per year (road segment id's 1-3 in Box 3) and together yield 52 tons $\mathrm{yr}^{-1}$ or $44 \%$ of the annual sediment load. The spatial distribution and delivery rates from individual road segments found throughout PDM reminds us that sediment pollution in this and most watersheds has a true non-point source nature but that particular road segments outweigh their counterparts in their relative contribution to watershed-scale sediment yields.

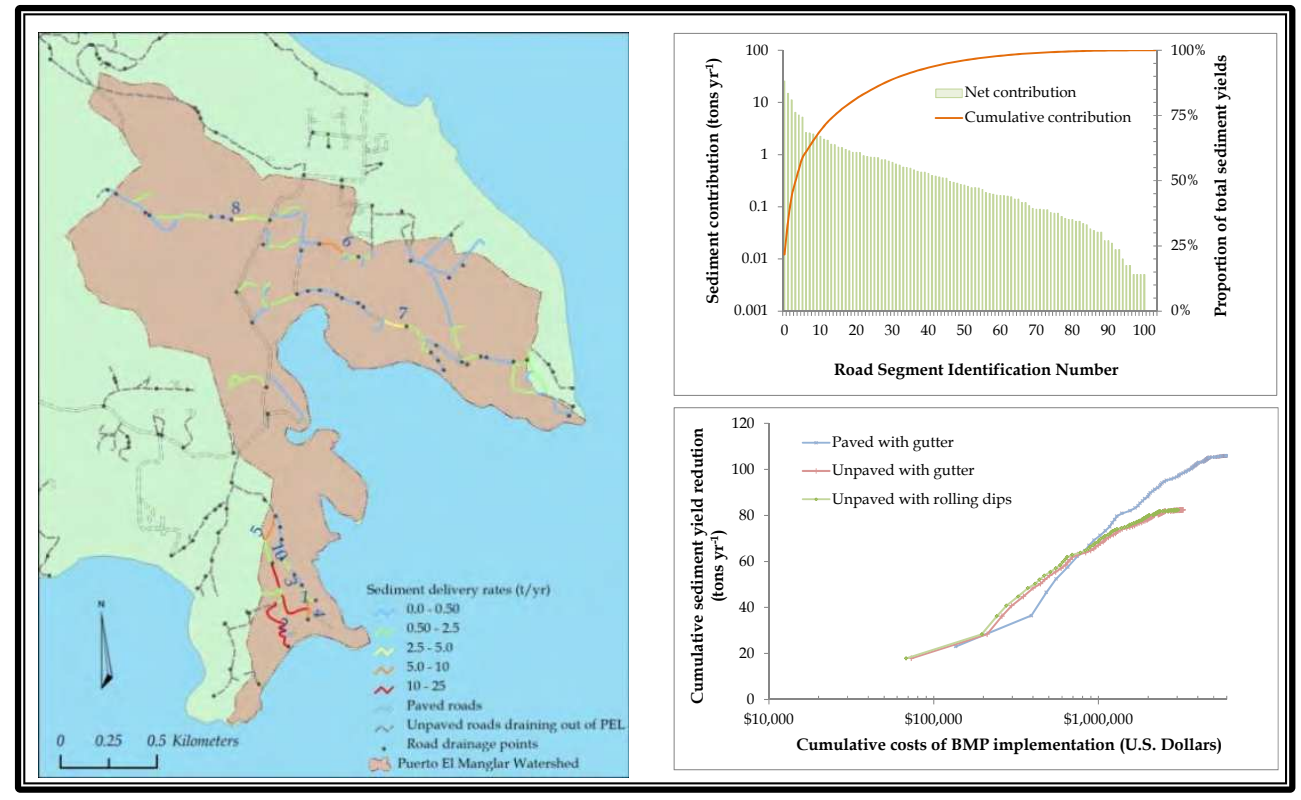

Box 3. Map contains another possibility for displaying the results of the STJ-EROS model by using a color-coded scheme to represent the amount of annual sediment contribution from individual unpaved road segments in the Puerto del Manglar (PDM) watershed. Numbers in the map represent the top-ten ranked road segments based on their individual sediment contribution estimates. Top-right graph displays the annual sediment contribution from each of the 104 unpaved road segments of the PDM and the cumulative proportion of the total estimated sediment yield. Bottom-right graph displays the relationship between cumulative implementation costs and cumulative reductions in sediment yields for the three treatment options described in Table 2. Cumulative costs and savings are consecutively added based on the sediment load rankings displayed on the top graph.

Paving all roads within PDM would reduce sediment yields by 106 tons $\mathrm{yr}^{-1}$ according to our estimates (Box 3). These reductions would imply a post-treatment sediment yield rate of 11 tons $\mathrm{yr}^{-1}$, or roughly $10 \%$ of pre-treatment levels (117 tons $\left.\mathrm{yr}^{-1}\right)$. These delivery rates 
would still be 13 times higher than background. Funds required to achieve this goal would amount to $\$ 6.1 \mathrm{M}$ for an overall cost-effectiveness measure of $\$ 57.7 \mathrm{~K}$ per ton reduced. The remaining discrepancy between post-treatment sediment delivery rates with background load levels and the costs required for achieving those levels highlight the unfeasibility of attempting to fully restore conditions to pre-disturbance rates. Road drainage improvements accomplished by placing rolling dips or paved gutters every $30 \mathrm{~m}$ on all road segments in PDM would reduce sediment yields by 82 tons $\mathrm{yr}^{-1}$ (Box 3). Post-treatment delivery rates would be 35 tons $\mathrm{yr}^{-1}$, or roughly $30 \%$ of pre-treatment levels. Costs related to the installation of the rolling dips and paved gutter treatments with their accompanying sediment check dams and energy dissipaters on all roads would cost $\$ 3.0 \mathrm{M}$ and $\$ 3.3 \mathrm{M}$, respectively. The overall cost-effectiveness measure would be $\$ 37.1 \mathrm{~K}$ per ton for the rolling dips method and $\$ 40.0 \mathrm{~K}$ ton $^{-1}$ for paved gutters, or $64 \%-69 \%$ more cost-effective (i.e., less expensive per unit ton reduced) than paving all roads. However, paving all roads would save the marine environment an additional 24 tons $\mathrm{yr}^{-1}$ that neither of the two road drainage improvement methods (i.e., rolling dips and paved gutters) would be able to achieve.

In reality, the high costs required for implementing treatments on all roads in PDM make this an unfeasible task. Therefore, devising a prioritization strategy is essential to establish price tags for different sediment reduction goals. Our analyses show that the best solution in terms of maximizing reductions while minimizing costs depends on the amount of funds available for treatment implementation (Box 3). If only roughly $\$ 70 \mathrm{~K}$ are available then the only feasible options are the two treatments involving drainage improvements, and these funds would only properly address one road segment (Site No. 1) and achieve a reduction of approximately 18 tons $\mathrm{yr}^{-1}$. If available funds range between $\$ 130 \mathrm{~K}$ and $\$ 200 \mathrm{~K}$ then the reductions in sediment yields achieved by the three treatment options would be very similar (25-28 tons $\left.\mathrm{yr}^{-1}\right)$, but if available funds range from $\$ 200 \mathrm{~K}$ to $\$ 700 \mathrm{~K}$ greater reductions would be achieved by road drainage improvements than by paving. Nevertheless, if funds exceed $\$ 700 \mathrm{~K}$ then road paving becomes a more favorable option than either of the other two treatment options.

It is important to note that the analysis presented here does not include other possible treatment scenarios. One possibility would be to further explore manipulating the ranking of individual road segments to attempt to further maximize the cost-effectiveness measure. Manipulations of site priority rankings for the PDM watershed did not display much difference to the one based simply on sediment yield contributions shown in Box 3, but this does not appear to be the case for some of the other seven watersheds studied. In addition, the analysis shown here does not explore applying a mix of the three treatments options and this might provide another alternative that generates more cost-effective results.

Although no spatial information was used to establish the priority ranking of the road segments, this kind of information should also be considered when making decisions. Roads with an obvious direct connectivity with the marine environment should be contemplated as high priority candidates. In the case of the PDM watershed, many of the top ranked sites based simply on annual sediment contribution (e.g., sites 1-5 and 10 in Box 3) not only show up as contributing large amounts of sediment but are also located in close proximity to the marine environment and are likely contributing sediment very effectively into coastal waters. 


\section{Conclusions}

High sediment delivery rates on highly erodible, anthropogenic-disturbed soils can have significant long-term deleterious impacts on coral reef biodiversity, sustainability, productivity, resilience, and on its ecosystem services, which could in turn affect its socioeconomic value and benefits to island communities. Reducing sediment loads into coastal marine ecosystems is one feasible mitigation activity by which humans can help alleviate a key stressor affecting coral reefs worldwide. The costs of implementing BMPs will always pose a limit to the type and extensiveness of erosion control efforts. Therefore, selecting priority areas, targeting the most relevant sediment sources, and choosing adequate BMPs to optimize efforts are critical steps in the development of effective erosion control plans. In this chapter we have presented an interdisciplinary approach to erosion mitigation that weighs information resulting from coral reef assessments, watershed analyses, and engineering considerations. The general framework described could also be used to help devise mitigation strategies for other non-point sources of pollution that also affect reefs and its associated ecosystems (i.e., seagrass communities, mangroves, estuarine systems). The addition of long-term coral reef community dynamics data as well as environmental parameter information (i.e., turbidity, high resolution sediment loading rates, sediment composition analysis, oceanographic currents, etc.) may further enhance the capacities of our proposed framework.

The interdisciplinary approach presented here was applied within the context of Isla de Culebra, part of the Puerto Rican archipelago in the Eastern Caribbean. The strategy serves in part to choose priority target watersheds for erosion control on the basis of the intentions of the mitigation efforts. Here we recognize that, depending on coral reef condition and sediment load rates, erosion mitigation efforts may have three different motivations: (1) to preserve reefs that are still in a good condition; (2) to prevent further damage to reefs that have a good to moderate condition but are being influenced by inland sediment sources; and (3) to remediate conditions for deteriorated reefs receiving high sediment loads. The approach also includes a cost-effectiveness analyses that aids in choosing specific sites and erosion control methods to maximize the net reductions in sediment loads while minimizing costs. Application of this cost-effectiveness analysis to one watershed in Culebra suggests that the choice of most effective erosion control method varies according to the amount of funds available for implementation. However, it is important to emphasize the need to strictly implement existing erosion-sedimentation regulations. Controlling the current rampant deforestation trends is crucial if further degradation of marine habitats in Culebra and throughout the rest of the Caribbean is to be prevented. The combination of climate change-related impacts and the cumulative degradation associated to localized anthropogenic factors, including negligent land use practices, may cause further irreparable coral reef decline if local stressor factors are not effectively managed and mitigated.

\section{Acknowledgements}

Funding for this project was provided through a contract with the Coastal Zone Management Program of the Puerto Rico Department of Natural and Environmental Resources (Federal Grant Number NA08NOS4190468). Partial funding to E.A. HernándezDelgado was provided by the Caribbean Coral Reefs Institute-University of Puerto Rico at Mayagüez, and by the National Science Foundation through grant NSF HRD 0734826 to the 
Center for Applied Tropical Ecology and Conservation at UPR Río Piedras. We kindly acknowledge the support provided by Mr. Ernesto Diaz and Mr. Raúl Santini (PR-DNER), and Mr. Samuel E. Suleimán-Ramos (Sociedad Ambiente Marino).

\section{References}

Anderson, D.M. (1994). Guidelines for Sediment Control Practices in the Insular Caribbean. CEP Technical Report No. 32, United Nations Environment Programme-Caribbean Environment Programme, $58 \mathrm{p}$.

Aronson, R.B., Mcintyre, I.G., Precht, W.F., T.J.T. Murdoch, \& Wapnick, C.M. (2002). The expanding scale of species turnover events on coral reefs in Belize. Ecological Monographs, Vol. 72, No. 2, pp. 233-249.

Ballantine, D.L., Appeldoorn, R.S., Yoshioka, P., Weil, E., Armstrong, R., García, J.R., Otero, E., Pagán, F., Sherman, C., Hernández-Delgado, E.A., Bruckner, A., \& Lilyestrom, C. (2008). Biology and ecology of Puerto Rican coral reefs. In, B.M. Riegl \& R.E. Dodge (eds.), Coral Reefs of the World, Vol. I. Coral Reefs of the USA, Springer-Science + Business Media B.V., pp. 375-406.

Beinroth, F.H., Engel, R.J., Lugo, J.L., Santiago, C.L., Ríos, S., \& Brannon, G.R. (2003). Updated taxonomic classification of the soils of Puerto Rico, 2002. Agricultural Experiment Station, Bulletin No. 303, University of Puerto Rico-Mayaguez, 73 p.

Bellwood, D.R., Hughes, T.P., Folke, C., \& Nyström. (2004). Confronting the coral reef crisis. Nature, Vol. 429, pp. 827-833.

Berman-Santana, D. (1996). Kicking Off the Bootstraps- Environment, Development, and Community Power in Puerto Rico, The University of Arizona Press, ISBN 0-81651590-5, Tucson, AZ.

Biagi, N. (1965). Puerto Rico's water pollution image. Water Pollution Federation Journal, Vol. 37, No. 3, pp. 381-391.

Biagi, N. (1968). The sugar industry in Puerto Rico and its relation to the industrial waste problem. Water Pollution Federation Journal, Vol. 40, No. 8, Part I, pp. 1423-1433.

Birdsey, R.A. \& Weaver, P.L. (1987). Forest Area Trends in Puerto Rico. USDA-US Forest Service, Research Note SO-331, New Orleans, LA, pp.

Bradshaw, A.D. (1997). What do we mean by restoration?. In: Restoration Ecology and Sustainable Development, K.M. Urbanska, N.R. Webb, \& P.J. Edwards (eds.), Cambridge University Press, Cambridge, UK, pp. 8-14.

Bradshaw, A.D. (2002). Introduction and philosophy. In: Handbook of Ecological Restoration- Volume 1: Principles of Restoration, Perrow, M.R, \& Davy, A.J. (eds.), Cambridge University Press, Cambridge, UK, pp. 3-9.

British Columbia Ministry of Forests. (2002). Forest road engineering guidebook. B.C. Ministry of Forests, Forest Practices Code of British Columbia Guidebook, Victoria, BC, 208 p.

Brooks, G.R., Devine, B., Larson, R.A., Rood, B.P. (2008). Sedimentary development of Coral Bay, St. John, USVI: A shift from natural to anthropogenic influences. Caribbean Journal of Science, Vol. 43, No. 2, pp. 226-243.

Buddemeier, R.W., Jokiel, P.L., Zimmerman, K.M., Lane, D.R., Carey, J.M., Bohling, G.C., \& Martinich, J.A. (2008) A modeling tool to evaluate regional coral reef responses to changes in climate and ocean chemistry. Limnology and Oceanography: Methods, Vol. 6, pp. 395-411. 
Buddemeier, R.W., Lane, D.R., \& Martinich, J.A. (2010). Modeling regional coral reef responses to global warming and changes in ocean chemistry: Caribbean case study. Climatic Change, DOI10.1007/s10584-011-0022-z, pp. 1-23

Burke, L. \& Maidens, J. (2004). Reefs at Risk in the Caribbean, World Resources Institute, Washington, DC, $5 \mathrm{p}$.

Clark, M.J. (1997). Ecological restoration - the magnitude of the challenge: an outsider's view. In: Restoration Ecology and Sustainable Development, Urbanska, K.M., Webb, N.R., \& Edwards, P.J. (eds.), Cambridge University Press, Cambridge, UK, pp. 353-377.

Cloern, J.E. (2001). Our evolving conceptual model of the coastal eutrophication problem. Marine Ecology Progress Series, Vol. 210, pp. 223-253.

Commonwealth of Puerto Rico \& NOAA. (2010). Puerto Rico's Coral Reef Management Priorities. NOAA, Silver Springs, MD. 40 p.

Concepción, C.M. (1988). El conflict ambiental y su potencial hacia un desarrollo alternative: el caso de Puerto Rico. Ambiente y Desarrollo, Vol. IV, No. 1 y 2, pp. 125-135.

Croke, J., Mockler, S., Fogarty P., \& Takken, I. (2005). Sediment concentration changes in runoff pathways from a forest road network and the resultant spatial pattern of catchment connectivity. Geomorphology, Vol. 68, pp. 257-268.

Dietz, J.L. (1986). Economic History of Puerto Rico: Institutional Change and Capitalist Development, Princeton University Press, ISBN 0-691-07716-9, Princeton, NJ, 337 p.

Estudios Técnicos Inc. (2004). Plan Maestro para el Desarrollo Sustentable de Culebra- Parte I: Análisis de Situación. Unpublished Report to Grupo Interagencial Vieques y Culebra, $187 \mathrm{p}$.

Estudios Técnicos Inc. (2007). Valoración económica de los arrecifes de coral y ambientes asociados en el este de Puerto Rico: Fajardo, Arrecifes de La Cordillera, Vieques y Culebra. Report submitted to the Department of Natural and Environmental Resources, San Juan, PR., pp. 1-99, + App.

Ewel, J.J. \& Whitmore, J.L. (1973). The ecological life zones of Puerto Rico and the U.S. Virgin Islands. US Forest Service Research Paper ITF-18, Río Piedras, PR, 72 p.

Fabricius, K.E. (2005). Effects of terrestrial runoff on the ecology of corals and coral reefs: review and synthesis. Marine Pollution Bulletin, Vol. 50, pp. 125-146.

García-Sais, J.; Appeldoorn, R.; Battista, T.; Bauer, L.; Bruckner, A.; Caldow C.; Carruba, L.; Corredor, J.; Díaz, E.; Lylyestrom, C.; García-Moliner, G.; Hernández-Delgado, E.; Menza, C.; Morell, J.; Pait, A.; Sabater, J.; Weil, E.; Williams, E. \& Williams, S. (2008). The State of Coral Reef Ecosystems of Puerto Rico. In, J.E. Waddell \& A.M. Clarke (eds.), The State of Coral Reef Ecosystems of the United States and Pacific Freely Associated States: 2008. NOAA Technical Memorandum NOS NCCOS 73. NOAA/NCCOS Center for Coastal Monitoring and Assessment's Biogeography Team, Silver Spring, MD., pp. 75-116.

Gardner, T.A.; Côté, I.M.; Gill, J.A.; Grant, A. \& Watkinson, A.R. (2003). Long-term regionwide declines in Caribbean corals. Science, Vol. 301, pp. 958-960.

Garrison, V.H., Shinn E.A., Miller, J., Carlo, M., Rodríguez, R.W., \& Koltes, K. (2005). Benthic cover on coral reefs of Isla de Culebra (Puerto Rico) 1991-1998 and a comparison of assessment techniques. US Geological Survey, Open-File Report 2005-1398.

Goenaga, C. (1991). The state of Puerto Rican corals: An aid to managers. Technical report submitted to the Caribbean Fishery Management Council, San Juan, PR., pp. 1-71. 
Goenaga, C., \& Cintrón, G. (1979). Inventory of the Puerto Rican coral reefs. Report submitted to the Department of the Department of Natural Resources, San Juan, PR., pp. 1-190.

Grau, H.R.; Aide, T.M.; Zimmerman, J.K.; Thomlinson, J.R.; Helmer, E. \& Zou, X. (2003). The ecological consequences of socioeconomic and land-use changes in postagriculture Puerto Rico. Bioscience, Vol. 53, No. 12, pp. 1159-1168.

Hawkins, J.P., \& Roberts, C.M. (2004). Effects of artisanal fishing on Caribbean coral reefs. Conservation Biology, Vol. 18, No. 1, pp. 215-226.

Hernández-Delgado, E.A. (2000). Effects of anthropogenic stress gradients in the structure of coral reef epibenthic and fish communities. Ph.D. Dissertation, Department of Biology, University of Puerto Rico, Río Piedras, P.R., pp. 1- 330.

Hernández-Delgado, E.A. (2004). Análisis del estado de los recursos y de la situación ambiental actual de la Reserva Natural del Canal Luis Peña, Culebra, P.R. Technical report submitted to the Culebra Conservation and Development Authority, Culebra, PR., pp. 1-133.

Hernández-Delgado, E.A. (2005). Historia natural, caracterización, distribución y estado actual de los arrecifes de coral Puerto Rico. In, R.L. Joglar (Ed.), Biodiversidad de Puerto Rico: Vertebrados Terrestres y Ecosistemas. Serie Historia Natural. Editorial Instituto de Cultura Puertorriqueña, San Juan, PR. pp. 281-356.

Hernández-Delgado, E.A. (2010). Thirteen years of climate-related non-linear disturbance and coral reef ecological collapse in Culebra Island, Puerto Rico: A preliminary analysis. In, E.A. Hernández-Delgado (ed.), Puerto Rico Coral Reef Long-Term Ecological Monitoring Program, CCRI-Phase III and Phase IV (2008-2010) Final Report. Caribbean Coral Reef Institute, Univ. Puerto Rico, Mayagüez, PR. pp. I.1I.62.

Hernández-Delgado, E.A., Alicea-Rodríguez, L., Toledo-Hernández, C.G. \& Sabat, A.M. (2000). Baseline characterization of coral reef epibenthic and fish communities within the proposed Culebra Island Marine Fishery Reserve, Puerto Rico. Proceedings of the Gulf and Caribbean Fisheries Institute, Vol. 51, pp. 537-556.

Hernández-Delgado, E.A., \& Rosado-Matías, B.J. (2003). Suplemento técnico al Plan de Manejo para la Reserva Natural del Canal Luis Peña, Culebra, Puerto Rico. II. Inventario biológico. Technical Report submitted to the Coastal Zone Management Program, Department of Natural and Environmental Resources. San Juan, PR., pp. $1-60$.

Hernández-Delgado, E.A., Lucking, M.A., \& González, R.L. (2003). Ecological impacts of private peer structures and operation on critical seagrass communities in Fulladosa Cove, Culebra, Puerto Rico. Tech. Rept. submitted to the US Corps of Engineers, San Juan, P.R., pp. 1- 61.

Hernández-Delgado, E.A., Vázquez, M.T., Díaz, A., Rentas, X., López, J.C., Cortés, K., Rainford, A.F., Colón, D., López, A., Rodríguez, A., Hernández, G., Navarro, I., Gómez, J., González, M., \& Hernández, S. (2003). Suplemento técnico al Plan de Manejo de la Reserva Natural del Canal Luis Peña, Culebra, Puerto Rico. III. Usos históricos, actuales y valor arqueológico del Canal Luis Peña. Technical Report submitted to the Coastal Zone Management Program, Department of Natural and Environmental Resources. San Juan, PR., pp. 1-45. 
Hernández-Delgado, E.A., Rosado-Matías, B.J., \& Sabat, A.M. (2006). Management failures and coral decline threatens fish functional groups recovery patterns in the Luis Peña Channel No-Take Natural Reserve, Culebra Island, PR. Proceedings of the Gulf and Caribbean Fisheries Institute, Vol. 51, pp. 577-605.

Hernández-Delgado, E.A.; Sandoz, B.; Bonkosky, M.; Norat-Ramírez, J. \& Mattei, H. (2010). Impacts of non-point source sewage pollution on Elkhorn coral, Acropora palmata (Lamarck), assemblages of the southwestern Puerto Rico shelf. Proceedings of the $11^{\text {th }}$ International Coral Reef Symposium, pp. 747-751.

Hernández-Delgado, E.A., \& Sandoz-Vera, B. (2011). Impactos antropogénicos en los arrecifes de coral. In, J. Seguinot-Barbosa (ed.), Islas en Extinción: Impactos Ambientales en las Islas de Puerto Rico. Ediciones SM, Cataño, pp. 62-72.

Hernández-Delgado, E.A., Suleimán, S., Olivo, I., Fonseca, J., \& Lucking, M.A.. (2011). Alternativas de baja tecnología para la rehabilitación de los arrecifes de coral. In, J. Seguinot-Barbosa (ed.), Islas en Extinción: Impactos Ambientales en las Islas de Puerto Rico. Ediciones SM, Cataño, PR, pp. 178-186.

Hernández-Pacheco, R., Hernández-Delgado, E.A. \& Sabat, A.M. (2011). Demographics of bleaching in the Caribbean reef-building coral Montastraea annularis. Ecosphere, Vol. 2, No. 1:art9. 1-13. doi:10.1890/ES10-00065.

Hoegh-Guldberg, O. (1999). Climate change, coral bleaching and the future of the world's coral reefs. Marine and Freshwater Resources, Vol. 50, pp. 839-866.

Hoegh-Guldberg, O., Mumby, P.J., Hooten, A.J., Steneck, R.S., Greenfield, P., Gomez, E., Harvell, C.D., Sale, P.F., Edwards, A.J., Caldeira, K., Knowlton, N., Eakin, C.M., Iglesias-Prieto, R., Muthiga, N., Bradbury, R.H., Dubi, A. \& Hatziolos, M.E. (2007). Coral reefs under rapid climate change and ocean acidification. Science, Vol. 318, pp. 1737-1742.

Hunter, J.M. \& Arbona, S.I. (1995). Paradise lost: An introduction to the geography of water pollution in Puerto Rico. Social Science and Medicine, Vol. 40, No. 10, pp. 1331-1355.

Jackson, J.B.C. (1997). Reefs since Columbus. Coral Reefs, Vol. 16, Suppl., pp. S23-S32.

Jackson, J.B.C. (2001). What was natural in the coastal oceans. Proceedings of the Natural Academy of Sciences, Vol. 98, No. 10, pp. 5411-5418.

Jackson, L.L., Lopoukhine, N., \& Hillyard, D. (1995). Ecological restoration: A definition and comments. Restoration Ecology, Vol. 3, No. 2, pp. 71-75.

Kendall, M.S., Monaco, M.E., Buja, K.R., Christensen, J.D., Kruer, C.R., Finkbeiner, M., \& Warner, R.A. (2001). Methods used to map the benthic habitats of Puerto Rico and the U.S. Virgin Islands. URL:

http://ccma.nos.noaa.gov/products/biogeography/usvi_pr_mapping/manual. pdf

Labadie-Eurite, J. (1949). La Mecanización Agrícola en Puerto Rico. Departamento de Instrucción, San Juan, PR, $31 \mathrm{p}$.

Larsen, M.C., \& Webb, R.M.T. (2009). Potential effects of runoff, fluvial sediments, and nutrient discharges on the coral reefs of Puerto Rico. Journal of Coastal Research, Vol. 25, No. 1, pp. 189-208.

Littler, M.M., Littler, D.S., Lapointe, B.E., \& Barile, P.J. (2006). Toxic cyanobacteria (bluegreen algae) associated with groundwater conduits in the Bahamas. Coral Reefs DOI 10.1007/s00338-005-0010-8, pp. 1-2. 
Littler, M.M., Littler, D.S., \& Brooks, B.L. (2006). Harmful algae on tropical coral reefs: Bottom-up eutrophication and top-down herbivory. Harmful Algae, Vol. 5, pp. 565585.

Loya, Y. (1976). Effects of water turbidity and sedimentation on the community structure of Puerto Rican corals. Bulletin of Marine Science, Vol. 26, No. 4, pp. 450-466.

MacDonald, L.H., Anderson, D.M., \& Dietrich, W.E. (1997). Paradise threatened: Land use and erosion on St. John, US Virgin Islands. Environmental Management, Vol. 21, No. 6, pp. 851-863.

Masson, D.G. \& Scanlon, K.M. (1991). The neotectonic setting of Puerto Rico. Geological Society of America Bulletin, Vol. 103, No. 1, pp. 144-154.

Megahan, W.F., \& Ketcheson, G.L. (1996). Predicting downslope travel of granitic sediments from forest roads in Idaho. Water Resources Bulletin, Vol. 32, pp. 371-382.

Meyerhoff, H.A. (1927). Geology of the Virgin Islands, Culebra and Vieques-Physiography. Scientific Survey of Porto Rico and the Virgin Islands, New York Academy of Sciences, Vol. IV, Part II, pp. 145-219.

Miller, J., Waara, R., Muller, E., \& Rogers, C. (2006). Coral bleaching and disease combine to cause mortality on reefs in US Virgin Islands. Coral Reefs, Vol. 25, pp. 418.

Miller, J., Muller, E., Rogers, C., Waara, R., Atkinson, A., Whelan, K.R.T., Patterson, M., \& Witcher, B. (2009). Coral disease following massive bleaching in 2005 causes $60 \%$ decline in coral cover on reefs in the U.S. Virgin Islands. Coral Reefs, Vol. 28, pp. 925-937.

Morelock, J.; Ramírez, W.R.; Bruckner, A.W. \& Carlo, M. (2001). Status of coral reefs southwest Puerto Rico. Caribbean Journal of Science, Special Publication No. 4, pp. 157.

National Oceanic and Atmospheric Administration-National Ocean Service-National Centers for Coastal Ocean Science Biogeography Program. (2001). Benthic Habitats of Puerto Rico and the U.S. Virgin Islands (CD-ROM). Silver Spring, MD, National Oceanic and Atmospheric Administration.

Oliver, L.M., Lehrter, J.C., \& Fisher, W.S. 2011. Relating landscape development intensity to coral reef condition in the watersheds of St. Croix, US Virgin Islands. Marine Ecology Progress Series, Vol. 427, pp. 293-302.

Pagán-Villegas, I.M., Hernández-Delgado, E.A., \& Vicente, V.P. (1999). Documento de designación de la Reserva Natural del Canal Luis Peña, Departamento de Recursos Naturales y Ambientales, San Juan, P.R., 21 de mayo de 1999.

Pandolfi, J.M.; Bradbury, R.H.; Sala, E.; Hughes, T.P.; Bjorndal K.A.; Cooke, R.G., McArdle D.; McClenachan L.; Newman, M.J.H.; Paredes, G.; Warner, R.R. \& Jackson, J.B.C. (2003). Global trajectories of the long-term decline of coral reef ecosystems. Science, Vol. 301, pp. 955-958.

Pandolfi, J.M., Jackson, J.B.C., Baron, N., Bradbury, R.H., Guzman, H.M., Hughes, T.P., Kappel, C.V., Micheli, F., Ogden, J.C., Possingham, H.P. \& Sala, E. (2005). Are U.S. coral reefs in the slippery slope to slime? Science, Vol. 307, pp. 1725-1726.

Pandolfi, J.M. \& Jackson, J.B.C. (2006). Ecological persistence interrupted in Caribbean coral reefs. Ecology Letters, Vol. 9, pp. 818-826.

Pastorok, R.A., \& Bilyard, G.R. (1985). Effect of sewage pollution on coral-reef communities. Marine Ecology Progress Series, Vol. 21, pp. 175-189. 
Puerto Rico Environmental Quality Board. (1970). An Island in Transition, Culebra 1970- A Staff Report on the Environment to the Governor's Special Committee on Culebra, $106 \mathrm{p}$.

Ramos-Scharron, C.E. (2004). Measuring and predicting erosion and sediment yields on St. John, US Virgin Islands. PhD Dissertation, Department of Geosciences, Colorado State University, Fort Collins, CO.

Ramos-Scharrón, C.E. (2009). The effects of land development on sediment loading rates into the coastal waters of the Islands of Culebra and Vieques, Puerto Rico. Unpublished report to the Coastal Zone Management Program of the Puerto Rico Department of Natural and Environmental Resources, San Juan, PR, 94 p.

Ramos-Scharrón, C.E. (2010). Sediment production from unpaved roads in a sub-tropical dry setting- Southwestern Puerto Rico. Catena, Vol. 82, pp. 146-158.

Ramos-Scharrón, C.E. (in press). Effectiveness of drainage improvements in reducing sediment production rates from and unpaved road. Journal of Soil and Water Conservation.

Ramos-Scharrón, C.E. \& MacDonald, L.H. (2005). Measurement and prediction of sediment production from unpaved roads, St. John, US Virgin Islands. Earth Surface Processes and Landforms, Vol. 30, pp. 1283-1304.

Ramos-Scharrón, C.E. \& MacDonald, L.H. (2007a). Measurement and prediction of natural and anthropogenic sediment sources, St. John, U.S. Virgin Islands. Catena, Vol. 71, pp. 250-266.

Ramos-Scharrón, C.E. \& MacDonald, L.H. (2007b). Development and application of a GISbased sediment budget model. Journal of Environmental Management, Vol. 84, pp. 157-172.

Restrepo, J.D \& Syvitski, J.P.M (2006). Assessing the effect of natural controls and land use change on sediment yield in a major Andean river: The Magdalena drainage basin, Colombia. Ambio, Vol. 35, No. 2, pp. 65-74.

Reilly, A.E. (1991). The effects of Hurricane Hugo in three tropical forests in the U.S. Virgin Islands. Biotropica, Vol. 23, No. 4a, pp. 414-419.

Rodríguez, A. (1981). Marine and coastal environmental stress in the Wider Caribbean Region. Ambio, Vol. 10, No. 6, pp. 283-294

Rogers, C.S., Garrison, G, Grober, R., Hillis, Z.M., \& Franke, M.A. (1994). Coral Reefs Monitoring Manual for the Caribbean and Western Atlantic. National Park Service, St. John, USVI.

Rudel, T.K.; Perez-Lugo, M. \& Zichal, H. (2000). When fields revert to forest: Development and spontaneous reforestation in post-war Puerto Rico. Professional Geographer, Vol. 52, No. 3, pp. 386-397.

Ryan, K.E., Walsh, J.P., Corbett, D.R., \& Winter, A. (2008). A record of recent change in terrestrial sedimentation in a coral-reef environment, La Parguera, Puerto Rico: A response to coastal development. Marine Pollution Bulletin, Vol. 56, pp. 1177-1183.

U.S. Army Corps of Engineers. (1995). Defense environmental restoration program for formerly used defense sites, ordnance and explosive waste, Archives Search Report, Findings for Culebra Island National Wildlife Refuge, Culebra, Puerto Rico, Project Number I02PR006802. Rock Island, Illinois. 
Valdés-Pizzini, M., González-Cruz M., \& Matínez-Reyes, J.E. (2011). La Transformación del Paisaje Puertorriqueño y la Disciplina del Cuerpo Civil de Conservación, 19331942. Centro de Investigaciones Sociales, Universidad de Puerto Rico, San Juan, PR.

Walling, D.E. (1983). The sediment delivery problem. Journal of Hydrology, Vol. 65, pp. 209237.

Webler, T., \& Jakubowski, K. (2011). Characterizing harmful behaviors of snorkelers and SCUBA divers to coral reefs in Puerto Rico. Interim Project Report. Preliminary Technical Report submitted to the Department of Natural and Environmental Resources, San Juan, PR, pp. 1-15.

Wolman, M.G. (1967). A cycle of sedimentation and erosion in urban river channels. Geografiska Annaler, Series A, Physical Geography, Vol. 49, No. 2/4, pp. 385-395.

Ziegler, A.D, \& Sutherland, R.A. (2006). Effectiveness of a coral-derived surfacing material for reducing sediment production on unpaved roads, Schoffield Barracks, Oahu, Hawaii. Environmental Management, Vol. 37, No. 1, pp. 98-110. 


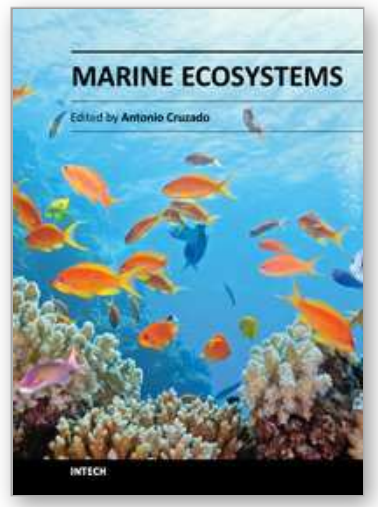

\author{
Marine Ecosystems \\ Edited by Dr. Antonio Cruzado
}

ISBN 978-953-51-0176-5

Hard cover, 310 pages

Publisher InTech

Published online 02, March, 2012

Published in print edition March, 2012

Marine ecosystems, a very wide topic, includes many different processes, groups of organisms and geographical peculiarities. The objective of this book is to present various topics of great importance for understanding the marine ecosystems, what they are, how they work and how we can model them in order to forecast their behaviour under changing conditions. They have been thoroughly reviewed and accepted for publication. The chapters cover aspects such as: Threats to ultraoligotrophic marine ecosystems (Ch. 1); Modelling the pelagic ecosystem dynamics: the NW Mediterranean (Ch. 2); The marine ecosystem of the Subantarctic, Prince Edward Islands (Ch. 3); Meiofauna as a tool for marine ecosystem biomonitoring (Ch. 4); Chemical interactions in Antarctic marine benthic ecosystems (Ch. 5); An Interdisciplinary Approach on Erosion Mitigation for Coral Reef Protection- A Case Study from the Eastern Caribbean (Ch. 6); A revisit to the evolution and ecophysiology of the Labyrinthulomycetes (Ch. 7); Seabed mapping and marine spatial planning: a case-study from a Swedish marine protected area (Ch. 8); Management strategies to limit the impact of bottom trawling on VMEs in the High Seas of the SW Atlantic (Ch. 9); Hydrocarbon contamination and the swimming behavior of the estuarine copepod Eurytemora affinis (Ch. 10), and Interactions between marine ecosystems and tourism on the Adriatic and Mediterranean (Ch. 11).

\title{
How to reference
}

In order to correctly reference this scholarly work, feel free to copy and paste the following:

Carlos E. Ramos-Scharrón, Juan M. Amador and Edwin A. Hernández-Delgado (2012). An Interdisciplinary Erosion Mitigation Approach for Coral Reef Protection - A Case Study from the Eastern Caribbean, Marine Ecosystems, Dr. Antonio Cruzado (Ed.), ISBN: 978-953-51-0176-5, InTech, Available from: http://www.intechopen.com/books/marine-ecosystems/an-interdisciplinary-erosion-mitigation-approach-forcoral-reef-protection-a-case-study-from-the-eas

\section{INTECH}

open science | open minds

\section{InTech Europe}

University Campus STeP Ri

Slavka Krautzeka 83/A

51000 Rijeka, Croatia

Phone: +385 (51) 770447

Fax: +385 (51) 686166

\section{InTech China}

Unit 405, Office Block, Hotel Equatorial Shanghai

No.65, Yan An Road (West), Shanghai, 200040, China 中国上海市延安西路65号上海国际贵都大饭店办公楼405单元

Phone: +86-21-62489820

Fax: $+86-21-62489821$ 
www.intechopen.com 
(C) 2012 The Author(s). Licensee IntechOpen. This is an open access article distributed under the terms of the Creative Commons Attribution 3.0 License, which permits unrestricted use, distribution, and reproduction in any medium, provided the original work is properly cited. 